\title{
Technological advances in suspended-sediment surrogate monitoring
}

\author{
John R. Gray ${ }^{1}$ and Jeffrey W. Gartner ${ }^{2}$ \\ Received 22 April 2008; revised 26 November 2008; accepted 30 December 2008; published 6 March 2009.
}

[1] Surrogate technologies to continuously monitor suspended sediment show promise toward supplanting traditional data collection methods requiring routine collection and analysis of water samples. Commercially available instruments operating on bulk optic (turbidity), laser optic, pressure difference, and acoustic backscatter principles are evaluated based on cost, reliability, robustness, accuracy, sample volume, susceptibility to biological fouling, and suitable range of mass concentration and particle size distribution. In situ turbidimeters are widely used. They provide reliable data where the point measurements can be reliably correlated to the river's mean cross section concentration value, effects of biological fouling can be minimized, and concentrations remain below the sensor's upper measurement limit. In situ laser diffraction instruments have similar limitations and can cost 6 times the approximate $\$ 5000$ purchase price of a turbidimeter. However, laser diffraction instruments provide volumetric-concentration data in 32 size classes. Pressure differential instruments measure mass density in a water column, thus integrating substantially more streamflow than a point measurement. They are designed for monitoring medium-to-large concentrations, are generally unaffected by biological fouling, and cost about the same as a turbidimeter. However, their performance has been marginal in field applications. Acoustic Doppler profilers use acoustic backscatter to measure suspended sediment concentrations in orders of magnitude more streamflow than do instruments that rely on point measurements. The technology is relatively robust and generally immune to effects of biological fouling. Cost of a single-frequency device is about double that of a turbidimeter. Multifrequency arrays also provide the potential to resolve concentrations by clay silt versus sand size fractions. Multifrequency hydroacoustics shows the most promise for revolutionizing collection of continuous suspended sediment data by instruments that require only periodic calibration for correlation to mean concentrations in river cross sections. Broad application of proven suspended sediment surrogate technologies has the potential to revolutionize fluvial sediment monitoring. Once applied, benefits could be enormous, providing for safer, more frequent and consistent, arguably more accurate, and ultimately less expensive sediment data for managing the world's sedimentary resources.

Citation: Gray, J. R., and J. W. Gartner (2009), Technological advances in suspended-sediment surrogate monitoring, Water Resour. Res., 45, W00D29, doi:10.1029/2008WR007063.

\section{Introduction}

[2] Fluvial sediment and sorbed materials are the most widespread pollutants affecting United States (U.S.) rivers and streams (http://iaspub.epa.gov/waters/national_rept. control\#TOP_IMP). The need for reliable, comparable, cost-effective, spatially and temporally consistent data to quantify the clarity and sediment content of waters of the U.S. has never been greater. The number of sites at which the U.S. Geological Survey (USGS) collected nationally consistent daily sediment data in 2006 was about a quarter of the number operated in 1981 (D. W. Stewart, personal communication, 2008). This precipitous decrease in sedi-

\footnotetext{
${ }^{1}$ U.S. Geological Survey, Reston, Virginia, USA

${ }^{2}$ U.S. Geological Survey, Tucson, Arizona, USA.
}

This paper is not subject to U.S. copyright.

Published in 2009 by the American Geophysical Union. ment monitoring over a quarter century by the USGS, the federal agency responsible for collecting, archiving, and disseminating the nation's water data, including fluvial sediment [Glysson and Gray, 1997], is due to a number of factors, principally cost [Gray, 2003a, 2003b]. The decrease in monitoring is of particular concern, given that the physical, chemical, and biological damages attributable to fluvial sediment in North America alone are estimated to range between $\$ 20$ billion and $\$ 50$ billion annually [Pimentel et al., 1995; Osterkamp et al., 1998, 2004]. Given this dearth in adequate, consistent, and reliable data describing fluvial sediment fluxes, decision makers responsible for mitigating its deleterious effects are at best hard-pressed to develop technically supportable management and remedial plans.

[3] Historically, riverine suspended sediment data in the U.S. have been produced by gravimetric analyses performed on water sediment samples collected manually or by automatic samplers [Edwards and Glysson, 1999; Bent et al., 
2003; Nolan et al., 2005; Davis, 2005; Gray et al., 2008]. These data collection methods tend to be expensive, difficult, labor intensive, and hazardous under some conditions. Specialized equipment and considerable training are prerequisites for obtaining reliable samples and results. The characteristic paucity of the derived data may be inadequate for defining the variability in suspended sediment concentrations (SSC) and particle size distributions (PSD), particularly for periods of storm runoff. Consequently, temporal interpolations and calibrations along with spatial corrections to the data are commonly required to develop the requisite SSC time series used with an associated time series of water discharge data to produce subdaily and daily records of suspended sediment discharges [Porterfield, 1972; Koltun et al., 2006].

[4] Existing and emerging sediment surrogate technologies may provide the types and density of fluvial sediment data needed to improve sediment discharge computations in a range of river types and sedimentological conditions [Gray and Gartner, 2004]. Potentially useful instruments and methods for inferring selected physical characteristics of fluvial sediments [Gartner et al., 2003; Bogen et al., 2003; Gray, 2005; Gray et al., 2003b, 2003c] are being developed and tested around the world. Through the informal Sediment Monitoring Instrument and Analysis Research Program [Gray, 2003a, 2003b], the USGS is testing instruments operating on bulk optic (turbidity), laser optic, pressure difference, and acoustic backscatter principles in U.S. rivers and in laboratory settings for measuring selected characteristics of suspended sediment, bed load, and bed material. To make the transition from research to operational applications, these new technologies must be rigorously tested with respect to accuracy and reliability in different physiographic settings, and their performances must be compared to the aforementioned traditional techniques. The performance comparisons should include concurrent collection of data by traditional and new techniques for a sufficient "shake-out" period, probably years, to identify and minimize changes in bias and precision between the old and new technologies.

[5] Even after the "shake-out" period, each of the four in situ technologies will require periodic calibration in field applications to define the relation of the surrogate measurement to the mean value in the cross section [Porterfield, 1972]. However, the need for routine calibration is expected to diminish over time.

[6] None of the technologies examined herein represents a panacea for sediment monitoring at all rivers under all flow and sediment transport conditions. However, with careful matching of proven monitoring technologies to the physical and sedimentological characteristics of selected river reaches, it may be possible in the coming years to remotely and continuously monitor suspended sediment discharges, in some cases by particle size class, with sufficient reliability to store the information as publicreleasable data in the USGS National Water Information System (http://waterdata.usgs.gov/nwis). Calculation and publication of some uncertainties associated with variables used in computations of SSC and suspended sediment discharge records in a variety of river types over a large range of flow and sedimentary regimes may also be possible
(http://ks.water.usgs.gov/Kansas/rtqw/sites/06892350/htmls/ 2005/p63680_2005 all uv.shtml).

[7] The prospect of large-scale application of proven suspended sediment surrogate technologies is a revolutionary concept in fluvial sedimentology when considered from a worldwide or even national perspective. The benefits of such applied capability could be enormous, providing for safer, more frequent and consistent, arguably more accurate, and ultimately less expensive fluvial sediment data collection for use in managing the world's sedimentary resources.

[8] This paper describes four commercially available surrogate technologies that operate on bulk optic (turbidity), laser optic, pressure difference, or acoustic backscatter principles for monitoring SSC and in some cases PSD. These technologies are being evaluated in field settings by the USGS with varying degrees of promise toward providing continuous, largely automated subdaily time series of SSC data in rivers. The paper begins with a description of traditional techniques for suspended sediment sampling, against which the surrogate technologies are evaluated. Descriptions of the theory, applications, evaluations, and some advantages and limitations of each technology are presented and compared.

\subsection{Background: Traditional Suspended Sediment Sampling Techniques in the United States}

[9] Instruments and methods for collecting fluvial-sediment data in the U.S. have evolved considerably since 1838 when Captain Andrew Talcott of the U.S. Army Corps of Engineers first sampled the Mississippi River [Federal Interagency Sedimentation Project, 1940]. The earliest suspended sediment samples were collected by use of instantaneous samplers, such as open containers or pails. By 1939, at least nine different types of sediment samplers were being used by U.S. agencies. Most of the samplers had been developed by independent investigators, lacked calibrations, and were deployed using a variety of methods. A 1930s survey of sediment sampling equipment used in the U.S. indicated that the 30 instantaneous samplers studied had limited usefulness either because of poor intake velocity characteristics or because of the short filament of watersediment mixture sampled [Federal Interagency Sedimentation Project, 1940; Nelson and Benedict, 1950; Glysson, 1989].

[10] In 1939, six federal agencies and the Iowa Institute of Hydraulic Research organized a committee to consider the development of sediment samplers, sampling techniques, and laboratory procedures and to coordinate such work among the federal agencies "actively concerned with the sedimentation problem" [U.S. Department of Agriculture, 1965]. This committee has evolved into the present-day Subcommittee on Sedimentation, Technical Committee, and Federal Interagency Sedimentation Project (FISP) [Skinner, 1989; Glysson and Gray, 1997; http://acwi.gov/sos/]. The purpose of the FISP is to study methods and equipment used in measuring the sediment discharge of streams and to improve and standardize equipment and methods where practicable.

[11] The bulk of suspended-sediment data obtained by federal agencies using traditional sampling techniques are collected by isokinetic samplers and methods developed by the Federal Interagency Sedimentation Project [2008] and described by Edwards and Glysson [1999], Davis [2005], Nolan et al. [2005], and Gray et al. [2008]. These include 


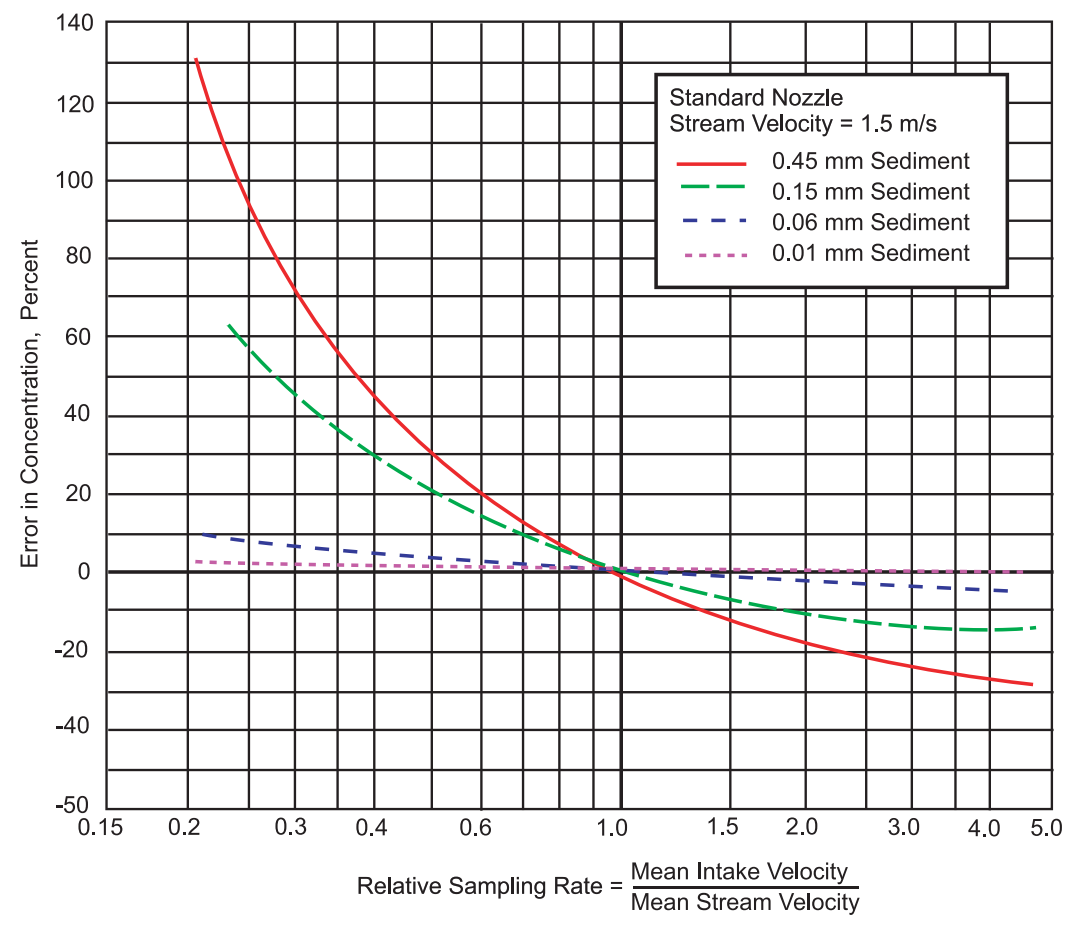

Figure 1. Effect of sampling rate on measured suspended-sediment concentrations for four sedimentsize distributions. From Gray et al. [2008]; adapted from the Federal Interagency Sedimentation Project [1941].

samplers with rigid sample bottles (bottle samplers) and flexible bags (bag samplers) that fill at a rate determined by the product of the ambient stream velocity at the sampler nozzle and the nozzle's area. These samplers, ranging in mass from 2 to $125 \mathrm{~kg}$, are designed to collect a representative velocity-weighted sample of the water-sediment mixture at the deployment location within the sampler's flow velocity and transit rate limits. FISP isokinetic samplers are designed to ensure that the water velocity entering the nozzle is within about 10 percent of the stream velocity incident on the sampler throughout the samplers' operable velocity range to minimize bias in SSC and PSD measurements. Figure 1 shows the effect of sampling rate on measured SSCs for four PSDs [Gray et al., 2008].

[12] A list of FISP samplers and selected attributes is provided by Davis [2005] and Gray et al. [2008]. Examples of a rigid-bottle sampler, the U.S. D-74, and a bag sampler, the U.S. D-96, are shown in Figure 2.

[13] When deployed using either the equal discharge increment (EDI) or equal width increment (EWI) sampling method [Edwards and Glysson, 1999; Nolan et al., 2005], an isokinetic sampler integrates a sample proportionally by velocity and area, resulting in a discharge-weighted sample that contains a concentration and size distribution representative of the suspended material in transport throughout the cross section at the time that the sample is collected.

[14] Although manual isokinetic samplers have considerable benefits, most notably the acquisition of demonstrably reliable suspended-sediment data from rivers, they have consequential drawbacks. For example, total noncapital costs associated with manual deployment of isokinetic samplers (about a half-person day for consecutive EDI or
EWI samples per site excluding transportation) and subsequent analytical costs (typically tens to hundreds of dollars depending on types of analyses) can be substantial with respect to available resources. Safety issues are paramount whenever a hydrographer works in, over, or near a stream. The time and effort required to collect manual samples by traditional methods precludes their use to resolve highfrequency sediment transport dynamics. The sparse temporal distribution of the derivative data, often a single observation or less per day, requires that daily load computations be based on estimated concentration values and (or) stochastically indexed to another more plentiful if imperfect predictive data source such as river discharge through sediment transport curves [Glysson, 1987; Gray and Simões, 2008].

\subsection{Performance Criteria for Data Produced by Sediment Surrogate Technologies}

[15] A number of advances in surrogate technologies used to compute SSCs and in some cases PSDs have been made in recent decades. However, verification data, particularly certifiably reliable verification data covering the broad range of flow and sedimentological conditions, are often lacking.

[16] Validation of a sediment surrogate technology requires evaluation criteria and a well-conceived and well-administered testing program [Gray et al., 2002; Gray and Glysson, 2005]. Following are some qualitative criteria for selecting and deploying a surrogate technology:

[17] 1. Capital, operating, and analytical costs should be affordable with respect to the objectives of the program in which the monitoring instrument is deployed. 


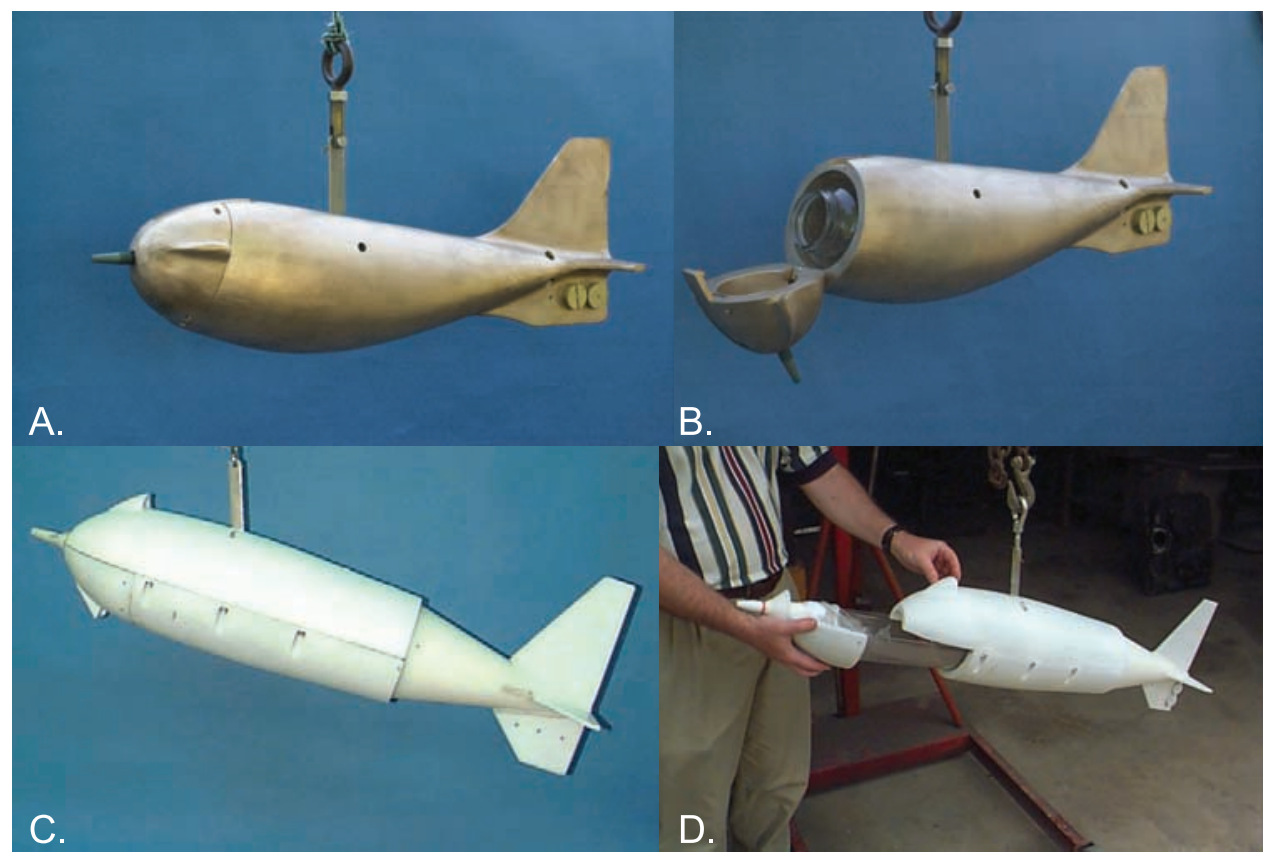

Figure 2. Two Federal Interagency Sedimentation Project suspended-sediment samplers: A U.S. D-74 suspended-sediment rigid bottle sampler (a) closed and (b) open; a U.S. D-96 flexible-bag suspendedsediment sampler (c) closed and (d) with tray containing flexible bag partially open.

[18] 2. The technology should be able to measure SSC, and in some cases PSD, throughout the range of interest.

[19] 3. The instrument should be robust and reliable; that is, prone to neither failure nor signal drift.

[20] 4. The technology should be sufficiently simple to deploy and operate by a field technician with a reasonable amount of appropriate training.

[21] 5. The derived data should be relatively simple and straightforward to use in subsequent computations and (or) accompanied by standard analytical procedures as computational routines for processing the derived data.

[22] Quantitative criteria for acceptable accuracies of the derived data are difficult to develop for all potential applications, in part because of significant differences in river sedimentary and flow regimes. For example, accuracy criteria for rivers transporting mostly silt and clay in suspension should be set more stringently (intolerant of larger-magnitude uncertainties) than those for rivers that transport comparatively large fractions of sand. However, there is a clear need for consistency in PSD and SSC criteria on the part of instrument developers, marketers, and users.

[23] To this end, acceptance criteria developed for PSD and SSC data produced by a laser diffraction instrument [Gray et al., 2002] have been generalized for evaluating data from any suspended sediment surrogate instrument. At least $90 \%$ of PSD values between 0.002 and $0.5 \mathrm{~mm}$ median diameter are required to be $\pm 25 \%$ of true median diameters. Absent a more rigorous evaluation, this criterion has been applied to all particle sizes in suspension.

[24] SSC acceptance criteria range from $\pm 50 \%$ uncertainty at lowest SSCs to $\pm 15 \%$ uncertainty for SSC's exceeding $1 \mathrm{~g} / \mathrm{L}$. The criteria presented in Table 1 are adapted from Gray et al. [2002].
[25] These criteria pertain solely to the performance of a surrogate technology within its physical realm of measurement. Routine calibrations to correlate instrument signals to mean cross-sectional SSC values are required for all of the in situ instruments presented herein.

[26] Because of the spatial and temporal variability in river sedimentological regimes, only generalities regarding the expected range of SSCs and PSDs in rivers can be made in the absence of site-specific data. Rainwater [1962] produced an empirically derived map of the 48 conterminous U.S showing mean SSCs for rivers (generalized for the entire land area) over seven logarithmically based SSC ranges. The SSC ranges were computed from measurements of the annual suspended sediment load divided by the annual streamflow. Computed SSC values in the largest range exceeded about $48 \mathrm{~g} / \mathrm{L}$. Using a similar computational scheme, Meade and Parker [1985] and the U. S. Geological Survey (http://co.water.usgs.gov/sediment/conc.frame.html) simplified the Rainwater [1962] map to show areas characterized by SSC in the following ranges: less than $0.3 \mathrm{~g} / \mathrm{L}$;

Table 1. Acceptance Criteria for Suspended-Sediment Concentrations $^{\mathrm{a}}$

\begin{tabular}{ccl}
\hline $\begin{array}{c}\text { Suspended-Sediment } \\
\text { Concentration } \\
\text { Minimum, g/L }\end{array}$ & $\begin{array}{c}\text { Suspended-Sediment } \\
\text { Concentration } \\
\text { Maximum, g/L }\end{array}$ & \multicolumn{1}{c}{$\begin{array}{c}\text { Acceptable } \\
\text { Uncertainty, \% }\end{array}$} \\
\hline 0 & $<0.01$ & 50 \\
0.01 & $<0.1$ & $50-25$ computed linearly \\
0.1 & $<1.0$ & $25-15$ computed linearly \\
1.0 & - & 15
\end{tabular}

${ }^{\text {a }}$ Suspended-sediment data produced are considered acceptable when they meet these criteria 95 percent of the time [Gray et al., 2002]. 
$0.3-2 \mathrm{~g} / \mathrm{L} ; 2-6 \mathrm{~g} / \mathrm{L}$; and more than $6 \mathrm{~g} / \mathrm{L}$. These maps can serve as initial, general indicators of the suitability of a selected sediment surrogate technology in a river reach of interest.

[27] Additional information on the range of SSCs in U.S. rivers is available from Smith et al. [1987], who computed percentile values for SSC data collected at 267 USGS streamgages in medium and large river basins as part of the original USGS National Stream Quality Accounting Network (NASQAN) (http://water.usgs.gov/nasqan/). The 25 th, 50th, and 75th SSC percentiles were 0.02, 0.07, and $0.19 \mathrm{~g} / \mathrm{L}$, respectively. In 1995 , the NASQAN network was redesigned to focus on the nation's largest rivers basins, the Mississippi (including the Missouri and Ohio), Columbia, and Colorado rivers and the Rio Grande. A. Horowitz (personal communication, 2008) calculated the 10th, 25th, 50th, 75th, and 90th SSC percentiles for the 41 NASQAN streamgages in these large river basins for the period 19942006 as $0.01,0.03,0.12,0.32$, and $0.74 \mathrm{~g} / \mathrm{L}$, respectively.

[28] Many streams transport near-zero SSCs at various times. On the other extreme, SSCs measured during surface runoff from 1989 to 1991 in the Little Colorado River basin, Arizona and New Mexico, commonly exceeded $100 \mathrm{~g} / \mathrm{L}$ [Graf et al., 1995]. Maximum SSC values measured at the USGS streamgage on the Paria River at Lees Ferry, Arizona, have exceeded $1000 \mathrm{~g} / \mathrm{L}$ [Beverage and Culbertson, 1964].

[29] In general, most of a river's annual sediment budget is transported during infrequent high-flow periods concomitant with high SSCs. Any proposed suspended sediment surrogate technology deployment should take into consideration not only the statistics quoted above but also the potential maximum SSC and, where appropriate, maximum particle sizes that might be transported in the period of interest.

[30] After surrogate technology efficacy is resolved, cost considerations are often of penultimate interest. The cost of producing reliable, quality-assured suspended sediment data can be separated into four categories: (1) the purchase price of the instrument; (2) other capital costs associated with installation and initial operation of the instrument; (3) operational costs to maintain and calibrate the instrument; and (4) analytical costs to evaluate, reduce, compute, review, store, and publish the derivative data.

[31] Of these four categories, only the current purchase price is straightforward to quantify. The others are dependent on a number of factors, including site location and physical characteristics, hydrological and sedimentological regime, availability of electrical power, limitations associated with accessibility, safety considerations, and the time and complexity associated with data analysis. Additionally, any such cost information inevitably becomes obsolete due, in part, to technological advances, marketing competition, and changes in currency valuation. Hence, the relative purchase prices are proffered for the surrogate instruments described herein versus the actual (summer 2008) purchase price for the most common of the instruments, an in situ fully equipped turbidimeter. In some instances, other relevant cost information for a given technology that is considered reliable is provided. That information may be considered in light of the fact that the cost to compute, store, and provide daily sediment discharge data at a USGS streamgage in 2001 (adjusted for inflation in 2008 dollars) ranged from $\$ 24,000$ to $\$ 78,000$ [Gray, 2003a].

\section{Technological Advances in Suspended Sediment Surrogate Monitoring}

[32] The need for more affordable time series data representing an expanded suite of measurements recorded on subdaily intervals at less risk to field personnel, coupled with advanced technological capabilities, is leading to a new era in fluvial sediment monitoring. The following sections describe theoretical principles [Gray and Gartner, 2004], selected examples of field applications, and advantages and limitations of four technologies considered by the USGS to hold varying degrees of promise for use in large-scale monitoring programs.

\subsection{Bulk Optics (Turbidity)}

\subsubsection{Background and Theory}

[33] Turbidity is an expression of the optical properties of a sample that causes light rays to be scattered and absorbed rather than transmitted in straight lines through the sample [Ziegler, 2003; Anderson, 2005]. Measurements of turbidity are the most common means for determining water clarity and computing SSCs in U.S. rivers [Pruitt, 2003].

[34] A number of commercially available optical instruments operate on one of two basic bulk-optic (hereafter referred to as turbidity) principles: transmissometry and nephelometry. Transmissometers employ a light source beamed directly at a light detector. The instrument measures the fraction of visible light from a collimated light source (typically at about $660 \mathrm{~nm}$ ) that reaches the detector. The fraction of light reaching the detector is converted to a beam attenuation coefficient, which is related to SSC.

[35] Nephelometry is the measurement of light scattering usually with a light detector at $90^{\circ}$ from the incident light (adapted from U.S. Environmental Protection Agency [1999]) in visible or infrared (IR) spectra. Most laboratory turbidimeters measure $90^{\circ}$ scattering. According to $D \& A$ Instrument Company [1991], optical backscatterance (OBS) instruments collectively are a type of nephelometer designed to measure backscattered $\left(140^{\circ}-165^{\circ}\right)$ IR in a small (concentration-dependent) volume on the order of a few cubic centimeters. Transmittance and scatterance are functions of the number, size, color, index of refraction, and shape of suspended particles [Conner and De Visser, 1992; Sutherland et al., 2000]. Figure 3 shows examples of five types of nephelometry sensors.

[36] A wide variety of turbidimeters are available for calculating SSC. For example, Landers [2003] describes bench tests as part of a workshop at which variances in measurements from nine different types of turbidimeters using blind reference samples were evaluated. One instrument that was first described in the early 1980s [Downing et al., 1981; Downing, 1983] and is now widely used for in situ applications is the OBS-3 (originally manufactured by the D\&A Instrument Company, now Campbell Scientific, Inc.). (Use of any trade or firm names in this report is for identification purposes only and does not constitute endorsement by the U.S. Government.)

[37] Turbidity instruments lack moving parts (unless outfitted with optical wipers), can be deployed in situ, and provide rapid-sampling capability. Site-specific empirical 


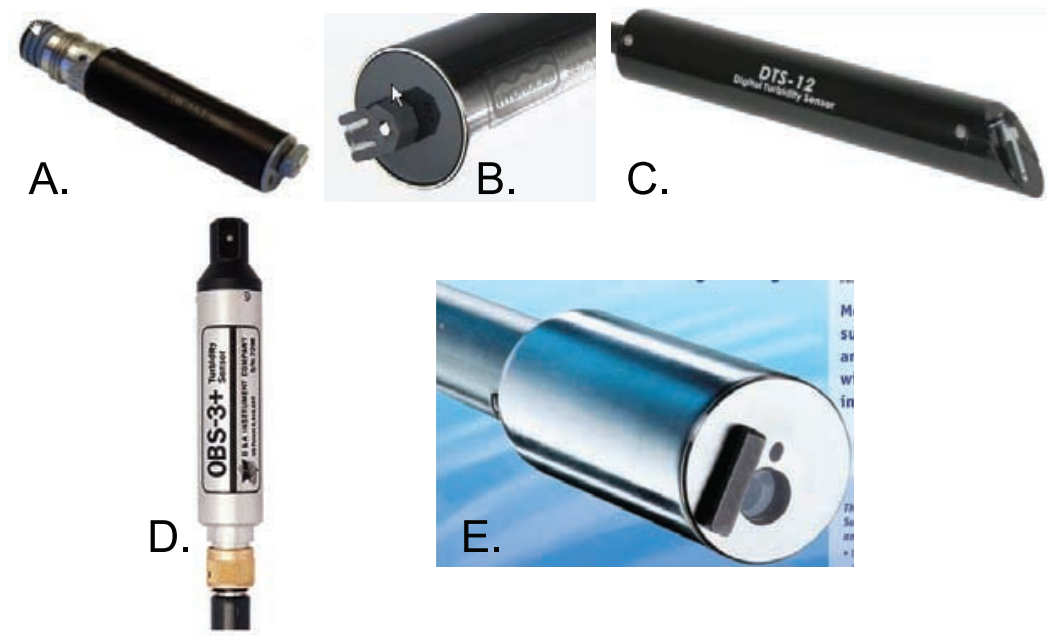

Figure 3. Photographs showing nephelometry sensors: (a) YSI model 6136, (b) Hydrolab turbidity sensor with wiper, and (c) Forrest Technology Systems model DTS-12. (d) D\&A Instrument Company model OBS 3+, and (e) Hach OptiQuant with wiper.

calibrations are required to convert measurements to reliable cross-sectional SSC estimates. The technology is relatively mature and has been shown to provide reliable data at a number of USGS streamgages [Schoellhamer and Wright, 2003; Melis et al., 2003; Uhrich, 2002; Uhrich and Bragg, 2003; Rasmussen et al., 2005] and other sites [Pratt and Parchure, 2003; Lewis, 2002]. The cost of an in situ turbidimeter with sonde (sensor), wiper, and controller in 2008 was about $\$ 5000$. The purchase price of an OBS without a wiper but with cable was about equal to the fully equipped in situ nephelometric turbidimeter cost.

[38] Maximum SSC limits for these instruments depend in part on PSDs. The OBS has a generally linear response at SSC less than about $2 \mathrm{~g} / \mathrm{L}$ for clay and silt and $10 \mathrm{~g} / \mathrm{L}$ for sand [Ludwig and Hanes, 1990], although Kineke and Sternberg [1992] describe the capability to measure SSC up to about $320 \mathrm{~g} / \mathrm{L}$ (in the nonlinear region of the OBS response curve). The specification sheet for the OBS-5+ manufactured by Campbell Scientific (http://www.campbellsci.com/index.cfm) lists an applicable range of up to $500 \mathrm{~g} / \mathrm{L}$ (specific gravity 1.3). The upper SSC limit for transmissometers depends on optical path length, but may be as low as about $0.05 \mathrm{~g} / \mathrm{L}$ [D\&A Instrument Company, 1991]. Thus, transmissometers are more sensitive at low SSC whereas optical backscatter sensors have superior linearity in turbid water [Downing, 1996]. In general, the wider a turbidimeter's turbidity measurement range, the less precise the withinrange derived turbidity data, and vice versa.

[39] Biological fouling of sensor optical windows remains a problem. Biological fouling results in a tendency for the output to shift from the calibration curve to spuriously larger values over timescales of days or more, particularly in warmer, microbiologically active waters. Commercially available mechanical wiper systems available with some sensors may alleviate this problem.

[40] Because of the relation between OBS signal response and PSD, OBS (like all single-frequency optical instruments) is best suited for application at sites with relatively stable PSDs. For a given mass SSC, OBS response increases with decreasing particle size [Conner and De Visser, 1992;
Downing, 1996; Sutherland et al., 2000]. OBS signal response is minimally affected by changes in PSD in the range of $200-400 \mu \mathrm{m}$ and greatly affected by changes when particles are smaller than about $44 \mu \mathrm{m}$ [Conner and De Visser, 1992]. Conner and De Visser [1992] caution against using OBS in environments where changes in PSDs occur and particle sizes are less than $100 \mu \mathrm{m}$. Additionally, the OBS signal can vary as a function of particle color. Sutherland et al. [2000] found a strong correlation between observed and predicted OBS measurements of varying SSC and ratios of black and white suspended sediment. They found the smallest OBS signal-gain response for black sediment and the largest for white sediment, with responses from other colors falling between. They suggest that the level of blackness of particles acts to absorb the near-infrared signal of the OBS, thus modifying its output. Hence, caution should be exercised in deployments under varying particle size and particle color conditions, unless the instrument is recalibrated for ambient conditions.

\subsubsection{Example Field Evaluation}

[41] Continuous turbidity measurements have been shown to provide reliable continuous SSC values with a quantifiable uncertainty at the USGS streamgage on the Kansas River at DeSoto, Kansas since the 1990s. Simple linear regression analysis explained by Christensen et al. [2000] was used to develop a site-specific univariate model using turbidity to compute SSC (Figure 4). The model explains about $93 \%$ of the variance in SSC. Continuous suspended sediment discharge values computed from the model and subdaily time series water discharge data are available online (http://ks.water.usgs.gov/Kansas/rtqw/sites/ 06892350/htmls/2005/p63680_2005_all_uv.shtml). The advantages of regression-based estimates üsing continuous turbidity measurements over discrete sample collection are that regardless of flow conditions, SSC and sediment discharge values are obtained essentially continuously at the interval in which water discharges are recorded.

[42] Some researchers are using variables in addition to turbidity to compute time series of SSC. J. D. Jastram et al. (A comparison of streamflow-based and turbidity-based estimates of suspended sediment concentrations in three 


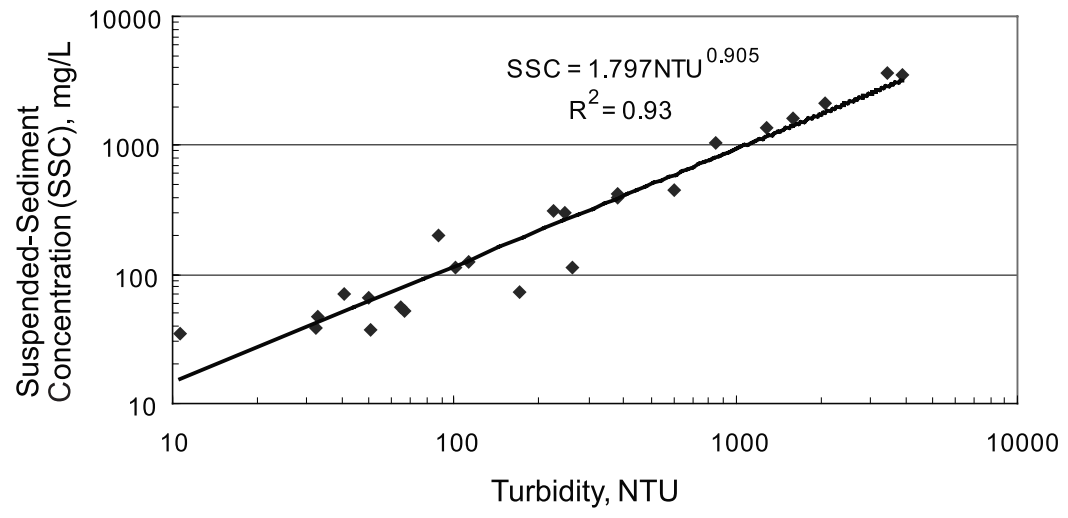

Figure 4. Linear regression comparing field turbidity in nephelometric turbidity units and instantaneous suspended-sediment concentrations in milligrams per liter for the Kansas River at DeSoto, Kansas, 1999 through 2002. From Gray et al. [2003a].

Chesapeake Bay tributaries, submitted to U.S. Geological Survey Scientific Investigations Report, 2009) have monitored turbidity at a USGS streamgage on the James River at Cartersville, Virginia, since 2003. Figure 5 shows a time series of computed SSC, sampled SSC, and streamflow data for this station from 22 October 2006 to 30 April 2007. The continuous SSC data were computed by a multiple regression technique from square root-transformed time series data describing turbidity, streamflow, and water temperature. The model explains about $97 \%$ of the variance in SSC.

[43] Schoellhamer et al. [2002] describe a multistation, multiyear field investigation to continuously monitor SSC in California's San Francisco Bay and Delta system that began in 1991. As of 2002, the program consisted of 13 monitoring stations (with OBS sensors at multiple depths) at which a cumulative 159 years of sensor data have been collected. OBS sensors are calibrated with water samples

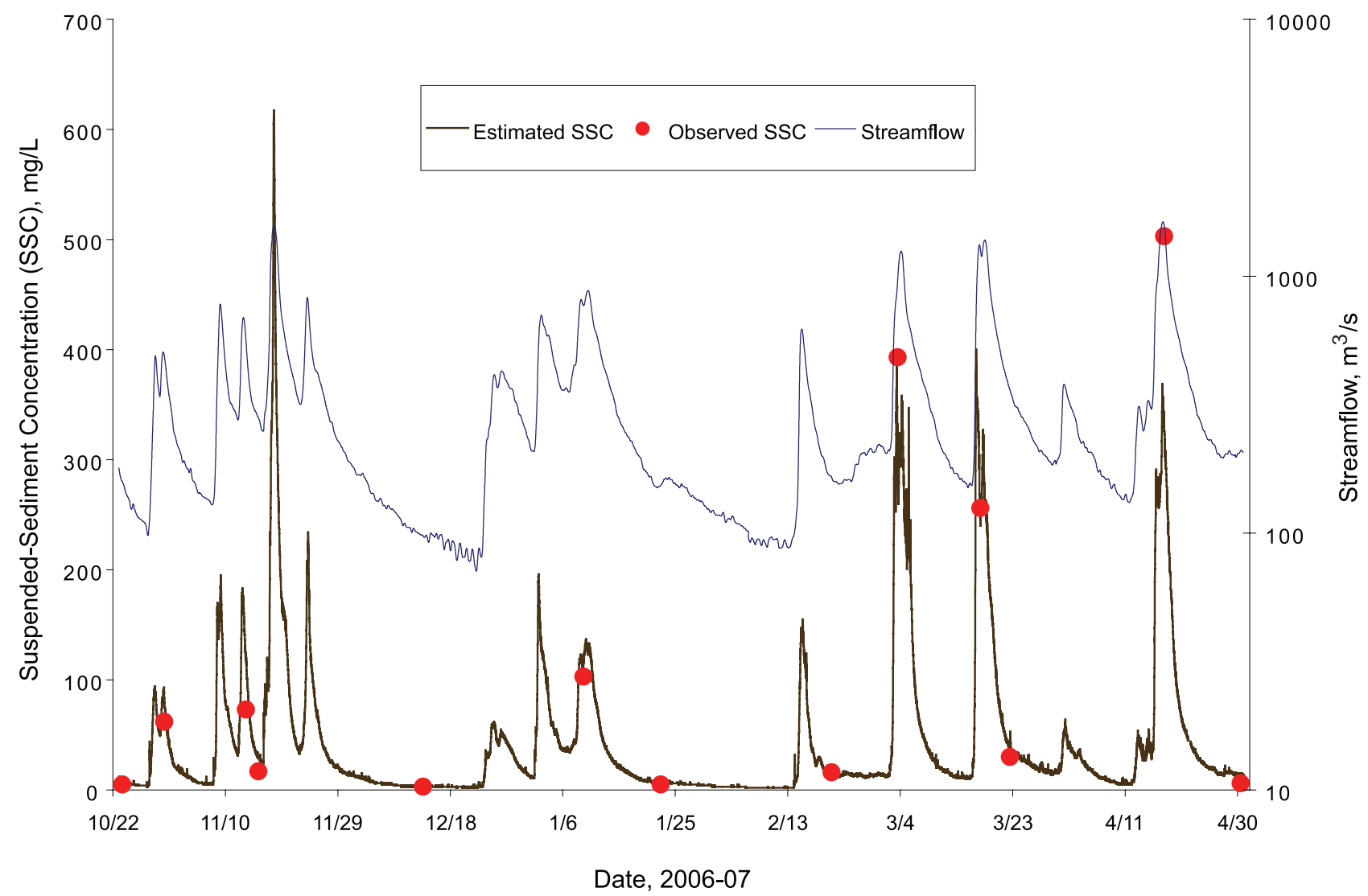

Figure 5. Time series plot of continuous suspended-sediment concentrations (computed by multiple linear regression from square root-transformed time series of turbidity, streamflow, and water temperature data), sampled SSCs in milligrams per liter, and streamflow in cubic meters per second for the James River at Cartersville, Virginia, 22 October 2006 to 30 April 2007. From Jastram et al. (submitted manuscript, 2009). 


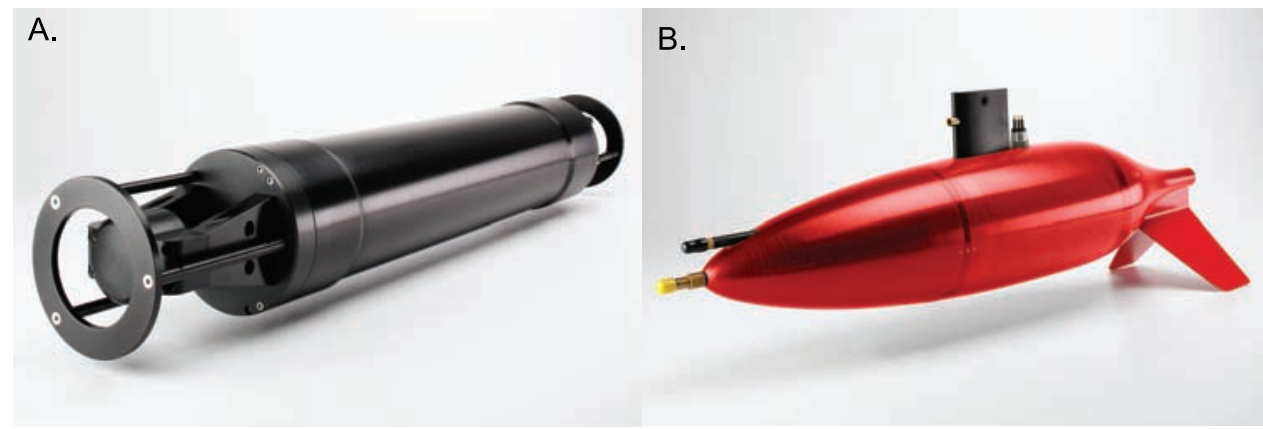

Figure 6. Laser in situ scattering and transmissometers: (a) a LISST-100 in situ instrument; (b) a LISST-SL (streamlined) manually deployable instrument. Photographs courtesy of Sequoia Scientific, Inc.

collected by Van Dorn sampler (or U.S. P-72 point sampler prior to 1994) [Davis, 2005] before and after sensor cleaning at each sensor location. As an example of data quality, results from the 1997 water year from 15 records at eight stations in San Francisco Bay had an average of about 59\% data considered acceptable (after deletion of records compromised by biological fouling and other factors). Calibration curves indicated generally good correlations between SSC samples and OBS voltage readings. The mean value for the correlation coefficient, $\mathrm{r}^{2}$, for the 15 records was 0.87 and ranged between 0.56 and 0.99 . Prior to October 1997, calibrations were performed using ordinary least squares regressions; starting with water year 1998, a robust, nonparametric, repeated median method was used (see Buchanan and Ruhl [2000] for a description of the method). San Francisco Bay sensors are calibrated to point measurements and Delta sensors are calibrated to discharge-weighted, crosssectionally averaged SSC values. Suspended sediment discharge is determined by multiplying the discharge-weighted, cross-sectionally averaged SSC by water discharge, accounting for tide-driven bidirectional flow [Schoellhamer et al., 2002].

[44] Advantages of turbidity technology are summarized as follows:

[45] 1. As the most ubiquitous of the field-deployed surrogate technologies, results from a large number of field settings are available for evaluation.

[46] 2. The technology is relatively mature and reliable.

[47] 3. Calibration techniques are documented and largely straightforward.

[48] 4. At a cost for a fully equipped turbidimeter of about $\$ 5000$, this is one of the more affordable sediment surrogate technologies.

[49] Limitations of the technology are summarized below:

[50] 1. The at-a-point turbidity time series data may not be representative of the sedimentary conditions in the river cross section.

[51] 2. Saturation of the turbidimeter signal can occur resulting in erroneous (constant) values for all SSC values that exceed a maximum value.

[52] 3. Biological fouling or damage to optical windows may require frequent site visits to service the instrument.

[53] 4. Instrument response to grain size, composition, color, shape, and coating can be variable and hence can reduce the accuracy of derived SSC values without additional calibration.
[54] 5. A lack of consistency in measurement characteristics among commercially available instruments impinges on the comparability of turbidity measurements.

\subsection{Laser Diffraction}

\subsubsection{Background and Theory}

[55] Laser diffraction instruments exploit the principles of small-angle forward scattering to infer PSDs. At small forward scattering angles, laser diffraction by spherical particles is essentially identical to diffraction by an aperture of equal size [Agrawal and Pottsmith, 1994]. Thus, this method of determining PSDs (and, by inference, volumetric SSC values) is mostly insensitive to changes in particle color or composition although departure from sphericity produces a bias in the computed PSD (compared to that for sieving). For example, Agrawal et al. [2008] have shown that natural particles measured by laser diffraction are inferred to be about $20-40 \%$ larger than identically sieved spheres.

[56] At present, an in situ version of this type of instrument is commercially available from only one manufacturer. First used in the early 1990s [Agrawal and Pottsmith, 1994], the present version of a laser diffraction instrument that can be deployed unattended to provide a time series of PSD and volume SSC values is the LISST-100, shown in Figure 6 (http://www.sequoiasci.com/default.aspx?SectionName= home). The Laser in Situ Scattering and Transmissometry (LISST) instrument uses a 32-ring detector to sense a laser beam defracted by sediment particles at small forward angles. These data are inverted to determine PSDs in 32 size classes between 1.25 and $250 \mu \mathrm{m}, 2.5-500 \mu \mathrm{m}$, or $7.5-$ $1500 \mu \mathrm{m}$ (LISST-FLOC). The standard sample path of this device is a cylindrical volume with a diameter of approximately $6 \mathrm{~mm}$ and a length of $50 \mathrm{~mm}$ (essentially a point measurement). An isokinetic, cable-suspended, streamlined version of the LISST-100, the LISST-SL shown in Figure 6, features the capability of real-time velocity measurement that is in turn used to control a pump to withdraw a filament of water and route it through the laser beam at the ambient current velocity [Gray et al., 2002; Gray and Gartner, 2004; Gray et al., 2004; Agrawal and Pottsmith, 2006]. The performance of the LISST-SL was evaluated by the Federal Interagency Sedimentation Project (http://fisp.wes.army.mil/) in a laboratory, a flume, and in the field. The purchase price of one of the LISST instruments (in situ or manually deployed) described in this section ranges from about 5 to 


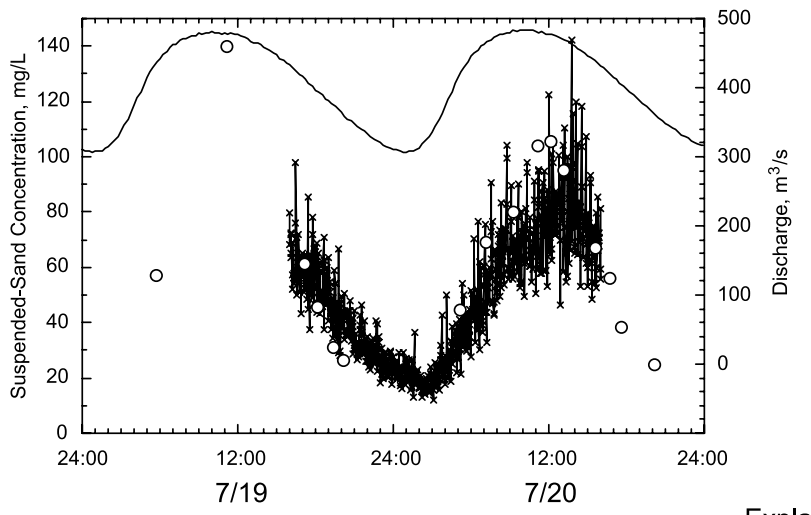

Date, 2001

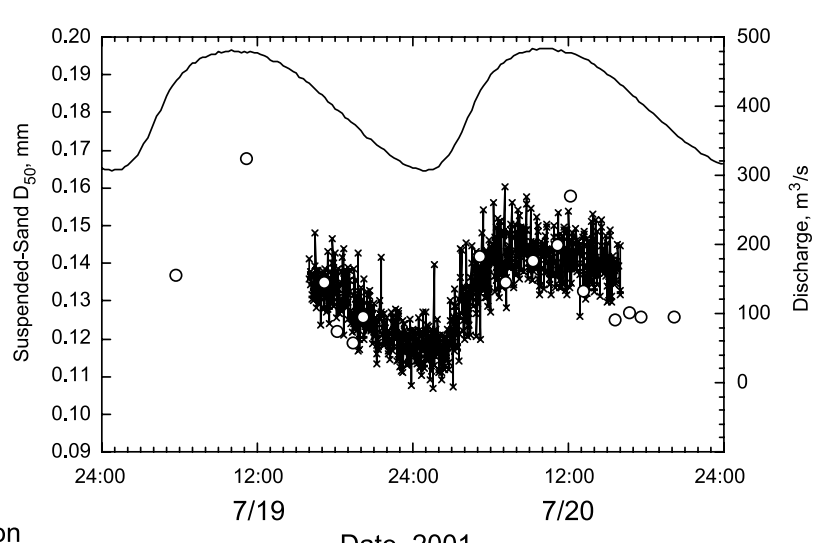

Date, 2001

* Calibrated LISST100B Point Measurement

- Cross-Sectionally Integrated with D-77 Sampler

Discharge of Water

Figure 7. Comparison of sand concentrations in milligrams per liter and median grain sizes in millimeters measured at the USGS streamgage at the Colorado River near Grand Canyon, Arizona, using a LISST-100B and a U.S. D-77 bag sampler. From Melis et al. [2003].

6 times that for a fully equipped turbidimeter, depending on the instrument of interest.

[57] Because a LISST determines PSD for all measurements, it is not subject to potential inaccuracies in the calculation of SSC associated with single frequency (optical and acoustic) instruments in the presence of changes in particle size distributions as long as particle sizes fall within the instrument measurement range [Agrawal and Pottsmith, 2000].

[58] Field and laboratory tests have shown the LISST-100 to be capable of determining PSDs of natural materials and the size of monosized particle suspensions with an accuracy of about 10\% [Traykovski et al., 1999; Gartner et al., 2001]. The LISST-100 can also be used to determine mass SSC from volume SSC if mean particle density is known from field calibrations or some other means [Gartner et al., $2001]$.

[59] As is the case with all types of in situ optical instruments, biological fouling can degrade measurements. Antifouling shutters for some LISST instruments are available from the manufacturer. In addition, the technology has a SSC range limitation associated with multiple scattering in the presence of high SSCs. The LISST-100 requires about $30 \%$ or more laser optical transmission. The range limitation is a function of the laser path length, PSDs, and SSCs. For SSC, the useable limits range from tenths of a $\mathrm{g} / \mathrm{L}$ (small particle sizes) to several $\mathrm{g} / \mathrm{L}$ (larger particle sizes). Optical blocks that reduce the path length by 50,80 , or $90 \%$ are available; reducing the optical path from the standard $5 \mathrm{~cm}$ to $5 \mathrm{~mm}$ can theoretically extend measurement limits from about $0.5 \mathrm{~g} / \mathrm{L}$ to about $5 \mathrm{~g} / \mathrm{L}$ for $25 \mu \mathrm{m}$ particles (Y. Agrawal, personal communication, 2008) [Agrawal et al., 2008]. A prototype LISST-INFINITE is being tested by the USGS [Konrad et al., 2006] for application in very high SSCs. The system pumps a water-sediment sample to the instrument and then uses automated multistage dilution (as necessary) before measuring PSDs and SSCs with a built-in LISST-100. However, the process of pumping the water sample from a point in the channel may alter the original PSD.
[60] A somewhat simpler and less expensive version of the LISST-100 instrument, the LISST-25, measures mean SSC and a mean particle size (Sauter mean size) in two size classes $(2.5-63 \mu \mathrm{m}$ and $63-500 \mu \mathrm{m})$ (http://www.sequoiasci. com/default.aspx?SectionName=home). This device is also based on the same small-angle scattering principles as the LISST-100, but it obtains the SSC through a weighted summation of the output of ring detectors, bypassing the inversion to PSD. The cost of the LISST-25 is about double that of a fully equipped in situ turbidimeter.

\subsubsection{Example Field Evaluation}

[61] Laser sensors are being investigated as an alternative monitoring protocol for tracking reach-scale suspended sediment supply at a USGS streamgage on the Colorado River near Grand Canyon, Arizona, located 164 km downstream from Glen Canyon Dam [Topping et al., 2004]. A canyon wall-mounted LISST-100B provides continuous suspended sediment transport data (SSCs, and PSDs in the range of $1.25-250 \mu \mathrm{m}$ ) that may reduce uncertainty in estimates of the transport of sand and finer material. An example of data collected by a LISST-100B at a fixeddepth, near-bank site on the Colorado River is shown in Figure 7. Data were obtained averaging 16 measurements at 2-min intervals during a 24-h deployment in July 2001. The time series of 720 LISST at-a-point measurements are compared with cross-sectional data obtained by U.S. D-77 isokinetic bag sampler concurrent with some of the LISST measurements using techniques described by Nolan et al. [2005]. In addition to accurately tracking sand-size SSCs, the LISST-100B also recorded the increase of variance in the SSCs of sand-size particles expected with increasing flows; peak sand-size SSC values ranged up to $0.15 \mathrm{~g} / \mathrm{L}$ (Figure 7).

[62] The FISP has performed laboratory bench tests of the sedimentological characteristics of a LISST-SL. The range in SSC used in tests was 0.01-3 g/L. Material used for testing was primarily less than $150 \mu \mathrm{m}$ although some tests included coarser material that was difficult to keep suspended in the test system. Sedimentological results from these LISST-SL tests fall within the acceptable uncertainty 
values for the corresponding SSC levels shown in Table 1

(B. Davis, personal communication, 2008).

[63] Advantages of laser optic technology are summarized as follows:

[64] 1. The instrument provides in situ or real-time PSD measurement in 32 size classes.

[65] 2. Calculated volumetric SSC values are not affected by changes in PSD.

[66] 3. A manually deployed isokinetic version of the LISST technology is available.

[67] The limitations of the technology are summarized below:

[68] 1. The at-a-point laser measurements may not be representative of sedimentary conditions in the river cross section.

[69] 2. Deviation of particle shape from spherical may bias results.

[70] 3. Saturation of the laser optic signal can occur at a SSC level of about half of that at which a standard in situ turbidimeter saturates.

[71] 4. Frequent field visits may be required to clean the optics if antifouling shutters are not used.

[72] 5. The cost of a LISST instrument is 2-6 times that for a fully equipped in situ turbidimeter depending on the instrument of interest.

\subsection{Pressure Difference}

\subsubsection{Background and Theory}

[73] The pressure difference technique for monitoring SSC relies on simultaneous measurements from two exceptionally sensitive pressure transducer sensors arrayed at different fixed elevations in a water column. The difference in pressure readings is converted to a water density value, from which SSC is inferred after correcting for water temperature (dissolved solids concentrations in fresh water systems are rarely of consequence in the density computation). Implicit assumptions are that the same water surface location is measured by both sensors and that the density of the water-sediment mixture above the lower sensor is more or less equal to that above the higher sensor. The technology has both laboratory and field applications [Lewis and Rasmussen, 1999]. One of the first uses of the pressuredifference technique was for monitoring the density of crude oil in pipes (W. Fletcher, personal communication, 1999).

[74] The 1999 purchase prices of the in situ field version of this technology and a fully equipped in situ turbidimeter were similar. The instrument evaluated by the USGS is no longer manufactured (http://www.waterlog.com/). However, the essential parts of the technology, precision pressure sensors, remain available from several commercial sources.

[75] The technique has been applied in the laboratory with promising results of better than $3 \%$ accuracy $(0.543 \pm$ $0.014 \mathrm{~g} / \mathrm{L}$ ) for determining mass concentrations of suspensions of glass microspheres [Lewis and Rasmussen, 1999]. However, application of this technique in the field can be complicated by low signal-to-noise ratios associated with low SSC, turbulence, significantly large dissolved solids concentrations, and water temperature variations. Additionally, analyses may be complicated by density variations in the suspended material. These complications coupled with the sensitivity limitations of the pressure-transducer sensors may render this technology unreliable at concentrations below $10-20 \mathrm{~g} / \mathrm{L}$.

\subsubsection{Example Field Evaluation}

[76] Information on the field performance of the pressuredifference technology is available from USGS streamgages on the lower Río Caguitas in Puerto Rico [Larsen et al., 2001] and the Paria River in Arizona. Continuous pressuredifference data were collected during October-December 1999 at the Río Caguitas streamgage using a Double Bubbler Pressure Differential Instrument, composed of a digital recorder, bubbler system, and two precision pressure sensors with orifices anchored at fixed depths in a vertical (http://www.waterlog.com/) (Figure 8). Most of the annual sediment discharge in the lower Rio Caguitas occurs as runoff from a few storms during which SSCs exceed about $0.5 \mathrm{~g} / \mathrm{L}$. The maximum SSC measured at the streamgage during the Puerto Rico Double Bubbler tests based on water samples collected by an autosampler [Edwards and Glysson, 1999] was $17.7 \mathrm{~g} / \mathrm{L}$.

[77] Data analyses involved data smoothing and removal of outliers. To calculate the weight density of suspended sediment and dissolved solids, the weight density of pure water at $27^{\circ} \mathrm{C}$ was subtracted from the smoothed data values. Even with these manipulations, the tests of the Double Bubbler instrument at the Puerto Rico site during October-December 1999 showed relatively poor agreement with discharge, SSC, and water density (Figure 9). The Double Bubbler data contained a large amount of signal noise, making interpretation difficult. Lacking a thermistor for temperature compensation, 12 of 15 base flow instrument measurements inferred negative SSC values (an impossibility) concomitant with in-stream measured SSC values of $0.01-0.1 \mathrm{~g} / \mathrm{L}$. However, all but two of the samples collected during seven higher-flow periods showed concomitant increases in inferred positive SSC values.

[78] A complicating factor in the pressure-difference method is in-stream turbulence, which introduces noise about equal to the magnitude of the signal of interest, particularly during high flows that occur more or less concomitant with the largest SSCs. Additionally, diel- and storm-related fluctuations in water temperatures resulted in a daily range as much as $10^{\circ} \mathrm{C}$. The high relative humidity characteristic of this humid tropical site may also complicate the use of the Double Bubbler because of the sensitivity of the narrow diameter bubbler gas lines to moisture, unless the gas lines are equipped with dryer tubes. This test of the Double Bubbler instrument showed the need for temperature compensation and possibly the need to deploy the instrument at a site where the range in the density of the water-sediment mixture is substantially larger than the 1.00-1.02 range occurring at the Río Caguitas streamgage during the Double Bubbler tests.

[79] In 2004, the Puerto Rico Double Bubbler system was transferred to the USGS streamgage on the Paria River at Lees Ferry, Arizona, where SSCs as high as $10^{3} \mathrm{~g} / \mathrm{L}$ have been measured during storm runoff. Deployment of the Double Bubbler in the Paria River was predicated on the hypothesis that Paria River SSC's, commonly exceeding peak measured Rio Caguitas concentrations by a factor of at least three and in some cases by $1-2$ orders of magnitude, would subject the instrument to a substantially larger density range than that inferred for higher flows at the Rio Caguitas streamgage in Puerto Rico. Even with the 

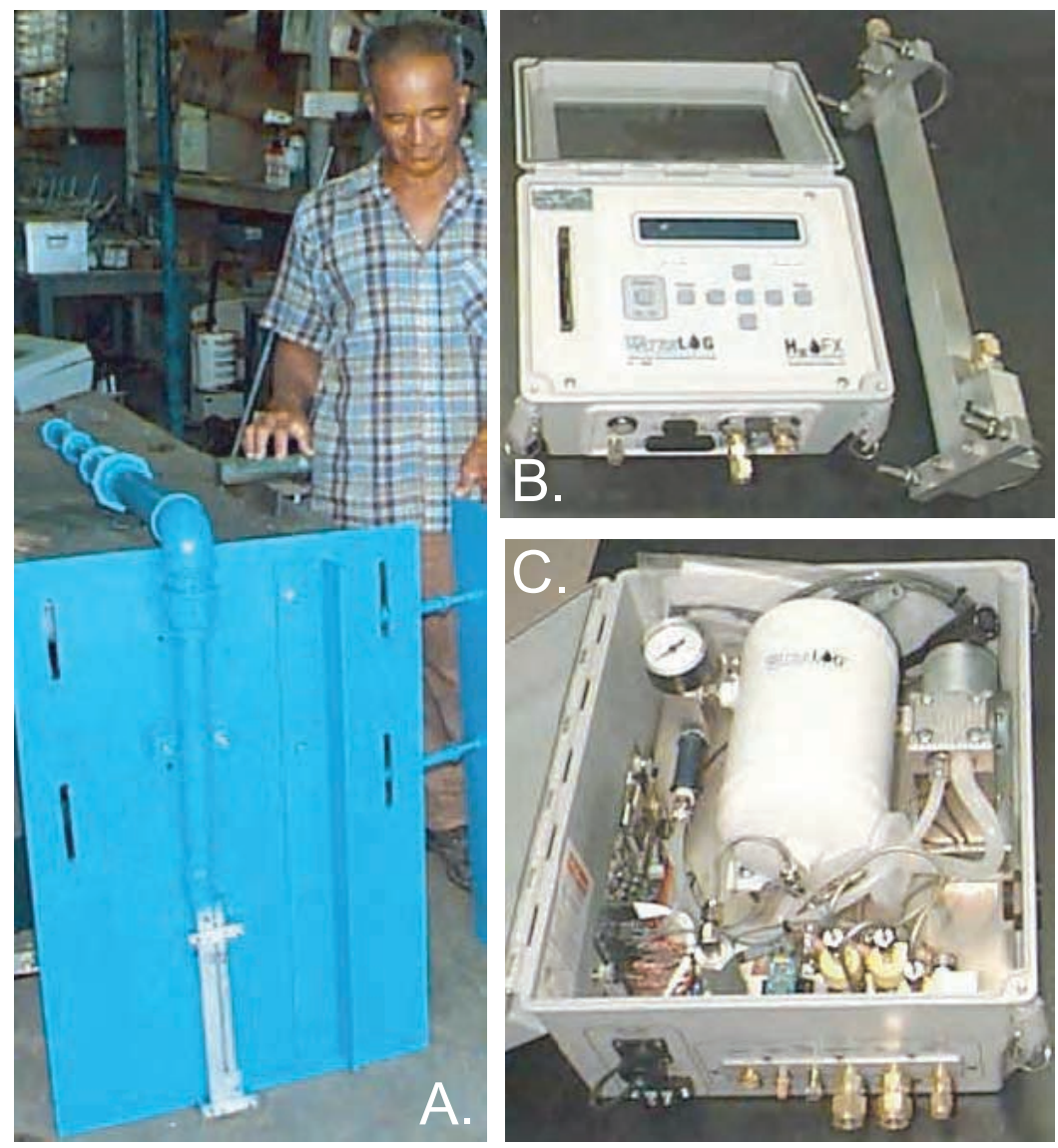

Figure 8. Double Bubbler Pressure Differential Instrument (a) in-stream components before installation, (b) controller and orifice bar, and (c) air compressor and tank assembly. Figures 8b and 8c courtesy of Design Analysis Associates, Inc.

addition of a thermistor for monitoring water temperatures, results to date have been mixed.

[80] Double Bubbler data were collected, at 5-min intervals, during periods of elevated flow at the Paria River streamgage from July 2004 through September 2006. Double Bubbler data collected from over 14 storm runoff hydrographs were examined and compared to SSCs from samples collected during storm runoff. The elevated flows had peaks ranging from about 7 to $90 \mathrm{~m}^{3} / \mathrm{s}$; the maximum SSC measured was $382 \mathrm{~g} / \mathrm{L}$ from a sample collected using an autosampler. Of the 261 suspended sediment samples collected during the 14 periods storm runoff periods, $86 \%$ had SSC values larger than $50 \mathrm{~g} / \mathrm{L}$ (N. Hornewer, personal communication, 2008).

[81] Similar to data collected at the Rio Caguitas in Puerto Rico and contrary to the aforementioned hypothesis, the Double Bubbler data collected at the Paria River at Lees Ferry streamgage seemed to have a large amount of signal noise, also making interpretation difficult. The Double Bubbler data were collected only during periods of elevated stages (discharges) because the instrument was not fully submerged during normal shallow flows. Data were filtered in a manner similar to that for the Río Caguitas data but not smoothed. Relations were between measured SSCs and those calculated from Double Bubbler data tended to be inconsistent. It is likely that bed movement caused the lower orifice to become partially or fully blocked at times, contributing to erroneous data. Also, the paired stage readings necessary for the density calculation could not always be obtained because both orifices were only submerged during infrequent periods of high flow.

[82] The performance of the Double Bubbler neither has been proven inadequate nor adequate for USGS data collection purposes. Because of this, its strong theoretical underpinnings, continuous monitoring capability, and, not unimportantly, a lack of any other proven technology for monitoring SSCs in high-concentrated and hyperconcentrated streamflow conditions, the pressure difference technique continues to be evaluated by the USGS.

[83] Advantages of the pressure differential technology are summarized as follows:

[84] 1. The pressure difference technology's inference of SSC in a single vertical is an improvement over at-a-point measurements but still may not provide SSC data representative of mean cross-sectional values.

[85] 2. The technology is relatively robust, being prone to neither signal drift nor biological fouling.

[86] 3. The technology doubles as a redundant stage sensor for the site.

[87] 4. The technology may be unique in that the accuracy of its measurements theoretically improves with concentrations increasing above about $10-20 \mathrm{~g} / \mathrm{L}$. 

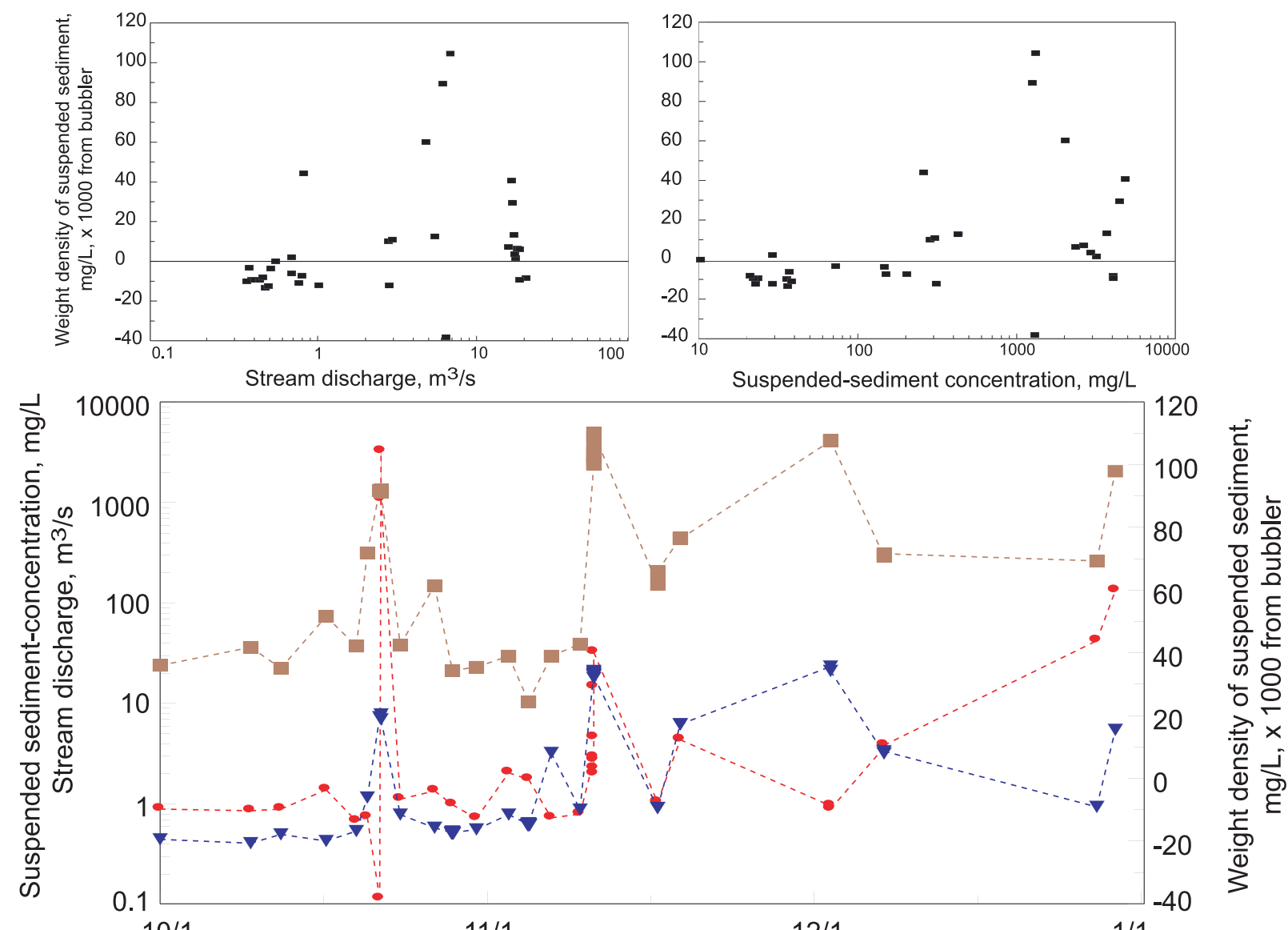

$10 / 1$

$11 / 1$

$12 / 1$

$1 / 1$

Date, 1999-2000

EXPLANATION

- Weight density of suspended sediment, $\mathrm{mg} / \mathrm{L}, \mathrm{x} 1000$, from bubbler Stream discharge,
$\mathrm{m}^{3} / \mathrm{s}$
Suspended-sediment concentration, $\mathrm{mg} / \mathrm{L}$

Note: Only symbols denote measure values; dashed interpolation lines are included for viewing purposes only.

Figure 9. Scatterplots and time series of stream discharges, SSCs, and weight density of suspendedsediments and dissolved solids measured with a Double Bubbler (Design Analysis Associates, Inc.), 1 October 1999 to 1 January 2000, lower Rio Caguitas, Puerto Rico. Discharge and sediment data are instantaneous values in cubic meters per second and milligrams per liter, respectively; Double Bubbler weight density values are expressed in milligrams per liter as 30-min mean values of measurements made at 5-min intervals. From Larsen et al. [2001].

[88] 5. The theoretical underpinnings of the technology are relatively simple and straightforward.

[89] The limitations of the technology are summarized below:

[90] 1. The required computational scheme presupposes that the concentration in the vertical profile above the lower pressure sensor is more or less constant to the surface. This assumption, which is difficult to verify, may not be valid.

[91] 2. The technology may be incapable of measuring SSCs below about $10-20 \mathrm{~g} / \mathrm{L}$ in turbulent flows and where the bed forms cover one or both orifices. The field performance of the technology has yet to be adequately resolved at any SSC.

[92] 3. The technology is incapable of measuring SSC when the top orifice is not submerged or the bottom orifice is buried in sediment.
[93] 4. Spurious data are numerous and are believed to be associated with flow turbulence.

[94] 5. The Double Bubbler is no longer marketed, and no other commercial source of this device is known by the authors. Those seeking to deploy this technology may have to construct their own system from commercially available parts.

\subsection{Acoustic Backscatter}

\subsubsection{Background and Theory}

[95] Attempts to characterize suspended sediments from acoustic backscatter measurements by prototype and commercial acoustic backscatter (ABS) instruments have increased in recent years. Utilization of acoustic backscatter measured by portable acoustic Doppler current profilers (ADCP), a byproduct of ADCP velocity measurements, is also appealing. In addition to being virtually immune to 
biological fouling, acoustic sensors such as commercially available ADCPs can provide nonintrusive estimates of SSC profiles concurrent with measurements of three-dimensional velocity data from the same instrument. As of 2008, such Doppler velocity instruments are available from about a half dozen manufacturers.

[96] The method of converting acoustic backscatter measured by ADCP to SSC has its basis in the sonar equation [Urick, 1975]. Theoretical aspects of the technique have been well documented [e.g., Thevenot et al., 1992; Reichel and Nachtnebel, 1994; Deines, 1999]. As with turbidity measurements, empirical calibrations are required to convert measurements to estimates of SSCs representative of the cross-sectional value. Postprocessing algorithms are complex, requiring compensations for physical properties of ambient water such as temperature, salinity, pressure, and suspended materials as well as instrument characteristics such as frequency, power, and transducer design [Thorne et al., 1991; Downing et al., 1995]. The information is necessary to properly account for acoustic signal transmission losses from the water (including nonspherical spreading in the transducer near field [Downing et al., 1995]) and, in some cases, attenuation from suspended materials in the water. Some commercial software products are available to convert backscatter to SSC [Land and Jones, 2001; Mol, 2003] although not yet widely used. Some researchers have written their own postprocessing software.

[97] The purchase price of a commercially available single-frequency Doppler in situ horizontal-looking instrument is about double to triple that of a fully equipped turbidimeter (no self-contained situ Doppler multifrequency version of this technology is yet commercially available). The purchase price of a bed-deployed upward looking instrument is about fourfold that for the turbidimeter. Because biological fouling has little if any effect on the performance of the sensor, field-maintenance costs are probably less than that for a turbidimeter. However, complexities in calibrating the acoustic signal to SSC and perhaps also PSD may increase analytical costs.

[98] Initial studies utilizing acoustics to estimate SSCs in the mid-1980s provided qualitative results, for example, Schott and Johns [1987], Flagg and Smith [1989], and Heywood et al. [1991]. Subsequent work attempted to quantify SSC estimates through laboratory or field calibrations of acoustic backscatter. Thevenot et al. [1992] developed calibration parameters as part of a study to monitor dredged material near Tylers Beach, Virginia, using Broadband-ADCPs (BB-ADCPs). Thevenot and Kraus [1993] compared optical and acoustic methods using a $2.4-\mathrm{MHz}$ BB-ADCP in the Chesapeake Estuary and Lohrman and Huhta [1994] undertook a sediment calibration experiment in the laboratory to determine the fate of suspended sediments during dredging operations. Jay et al. [1999] incorporated a correction function for improved calculation of beam spreading losses in the ADCP transducer near field to account for the complex acoustic beam pattern, and Holdaway et al. [1999] accounted for sediment attenuation in their evaluation of ADCPs to estimate SSC. More recently, Gartner [2004] estimated SSCs in San Francisco Bay using 1.2- and 2.4-MHz ADCPs, Lorke et al. [2004] applied acoustic backscatter to the distribution and movement of zooplankton, C. flavicans, populations in lakes, and
Wall et al. [2006] used ADCP backscatter data to compute suspended-sediment discharges in the lower Hudson River, New York. Comparisons of SSCs computed from acoustic backscatter with SSC determined from water samples have been found to agree within about 10-20\% [Thevenot et al., 1992; Thorne et al., 1991; Hay and Sheng, 1992].

[99] General limitations of the technique (especially when using single-frequency instruments) are also well described in the literature [e.g., Reichel and Nachtnebel, 1994; Hamilton et al., 1998]. Gartner [2004] provides a discussion of the theoretical background of the technique and some inherent limitations. One critical limitation is the fact that it is impossible to differentiate between a change in mass concentration and a change in PSD (without sufficient calibrations) when using a single-frequency instrument, as changes in both SSC and PSD can result in a change in the backscatter signal strength. In addition, there is an appropriate or optimum acoustic frequency for a given PSD. Errors in estimates of SSC will increase if a significant fraction of the suspended material includes particles that are too large or too small for a given frequency. For these reasons, techniques or instruments that utilize more than one acoustic frequency are preferable to single-frequency methods.

[100] Corrections for attenuation from suspended materials must be accounted for in the presence of significant SSCs of very small particles (where viscous losses may be substantial) or very large particles (where scattering losses may be high) [Flammer, 1962]. The method appears appropriate for use in SSCs up to several $\mathrm{g} / \mathrm{L}$ depending on acoustic frequencies and PSDs. Quantification of high SSCs may be problematic, especially when using high acoustic frequencies that are more prone to attenuation from sediment. The result is a nonlinear (backscatter intensity) response at high SSCs [Hamilton et al., 1998]. Although a function of frequency, attenuation from sediment should be accounted for in the presence of as little as $0.1 \mathrm{~g} / \mathrm{L}$ [Libicki et al., 1989; Thorne et al., 1991]; multiple scattering produces nonlinear response when SSC is on the order of $10 \mathrm{~g} / \mathrm{L}$ [Hay, 1991; Sheng and Hay, 1988].

\subsubsection{Example Field Application}

[101] A multiinstrument, multifrequency system has been established at the USGS streamgage Colorado River near Grand Canyon, Arizona, to produce data from which continuous SSCs and discharges can be computed [Topping et al., 2007]. The system utilizes three single-frequency side-looking acoustic Doppler profilers $(1.0$ and $2.0 \mathrm{MHz}$, and $600 \mathrm{kHz}$ ) (Figure 10) set to record 4 out of every $15 \mathrm{~min}$. For sand-size SSCs, the $1 \mathrm{MHz}$ acoustic data were calibrated with 345 EDI measurements between February 2003 and September 2005, the $2 \mathrm{MHz}$ acoustic data were calibrated with 74 EDI measurements between September 2004 and September 2005, and the $600 \mathrm{kHz}$ acoustic data were calibrated with 65 EDI measurements between September 2004 and September 2005. EDI measurements prior to April 2003 utilized U.S. D-77 bag samplers; subsequent measurements were made with U.S. D-96-A1 or U.S. D-96 depth-integrating bag samplers [Topping et al., 2007; Davis, 2005]. Calibrations were done with EDI measurements augmented by automatic pump samples collected under conditions of high silt and clay SSCs. 


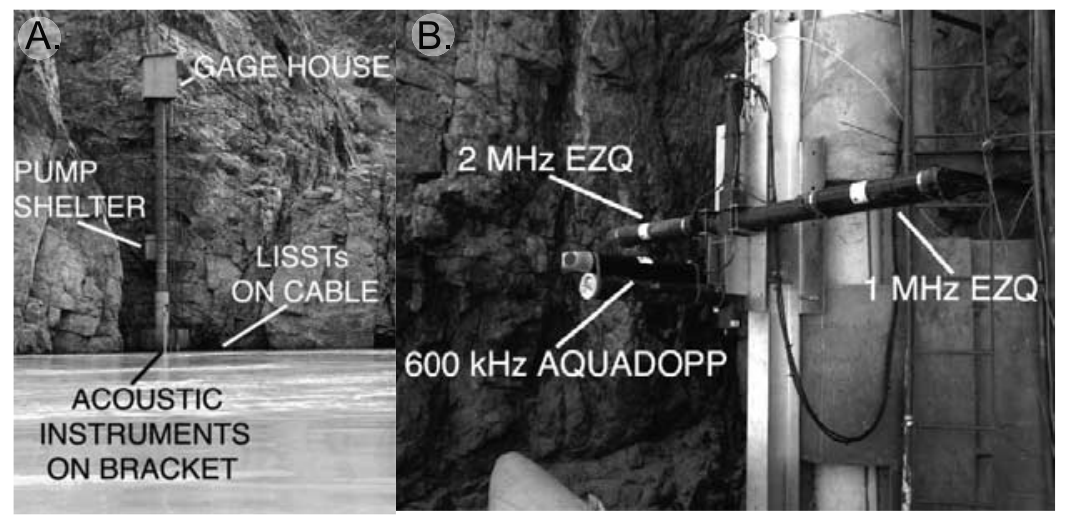

Figure 10. Photographs of (a) instrument locations and (b) an array of the three bracket-mounted acoustic Doppler profiler used to estimate suspended-sediment concentrations by silt-, clay-, and sand-size classes, at the USGS streamgage Colorado River near Grand Canyon, Arizona. From Topping et al. [2007].

[102] A postprocessing technique was employed for analyzing acoustic attenuation to compute the suspended siltand clay-size fraction and acoustic backscatter to compute the suspended sand fraction in a size range applicable for each frequency. Topping et al. [2007] indicate that the approach is applicable for monitoring SSCs over the ranges of $0.01-20 \mathrm{~g} / \mathrm{L}$ (silt and clay) and $0.01-3 \mathrm{~g} / \mathrm{L}$ (sand), with results within $5 \%$ of those computed by conventional means [Porterfield, 1972]. In addition, the method calculates median grain size within $10 \%$ of that measured by conventional means. Topping et al. [2007] infer a greater accuracy with this technique than with a conventional sampling regime $( \pm 10 \%$ for suspended silt and clay concentrations; $\pm 22 \%$ for suspended sand concentrations) largely due to the substantially greater sample frequency. Figure 11 shows comparisons of SSCs from three-frequency acoustic backscatter, calibrated pump, and LISST measurements.

[103] Wall et al. [2006] describe an ongoing study begun in July 2002 to use acoustic backscatter to compute suspended sediment discharge in the Hudson River near Poughkeepsie, New York. At that location, the Hudson River is about $18 \mathrm{~m}$ deep and $800 \mathrm{~m}$ wide; it is usually fresh water but experiences a mean tidal range of $0.95 \mathrm{~m}$. A $600 \mathrm{kHz}$ ADCP, set to average 100 acoustic pings for a measurement of velocity profile and acoustic backscatter every $15 \mathrm{~min}$, is deployed on the riverbed in an up-looking orientation. Vertical resolution (ADCP bin size) is set at $0.5 \mathrm{~m}$. Computation of SSC from the ADCP backscatter measurement is based on the exponential form of the sonar equation [see, e.g., Reichel and Nachtnebel, 1994; Deines, 1999; Gartner, 2004] but includes a variable for water temperature that Wall et al. [2006] found significant. As part of the postprocessing, they describe their process for normalizing echo intensity to account for variations in instrument transmit power and variations in acoustic beams. Measurements from a vessel-mounted ADCP and SSCs from water samples collected with a U.S. P-61 pointintegrating isokinetic sampler [Davis, 2005] have been used to relate acoustic backscatter to SSC. Analysis of water samples showed that particle sizes are generally smaller than $62 \mu \mathrm{m}$. Regression between $\log _{10} \mathrm{SSC}_{\text {measured }}$ and $\log _{10} \mathrm{SSC}_{\text {computed }}$ is considered acceptable with a coefficient of determination, $\mathrm{R}^{2}$, of 0.86 and a standard deviation of residuals equal to $7.9 \mathrm{mg} / \mathrm{L}$. The range of SSCs is about $5-65 \mathrm{mg} / \mathrm{L}$. Estimates of SSCs in the full river cross section made from moving boat are used to adjust estimates from the upward ADCP at fixed location in the river that continuously recorded measurements every $15 \mathrm{~min}$. Sus-

A.
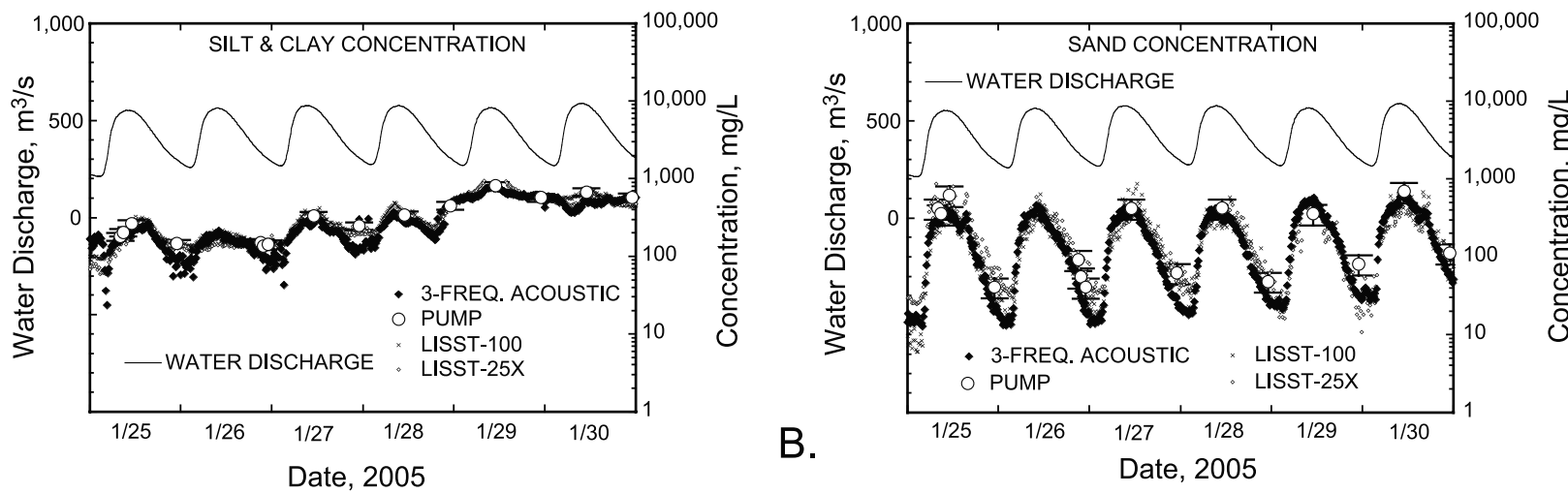

Figure 11. Comparisons of suspended-sediment concentrations in milligrams per liter from threefrequency acoustic backscatter, calibrated pump, and LISST-100 and LISST-25X measurements: (a) suspended silt- and clay-size concentrations and (b) suspended sand concentrations. From Topping et al. [2007]. 


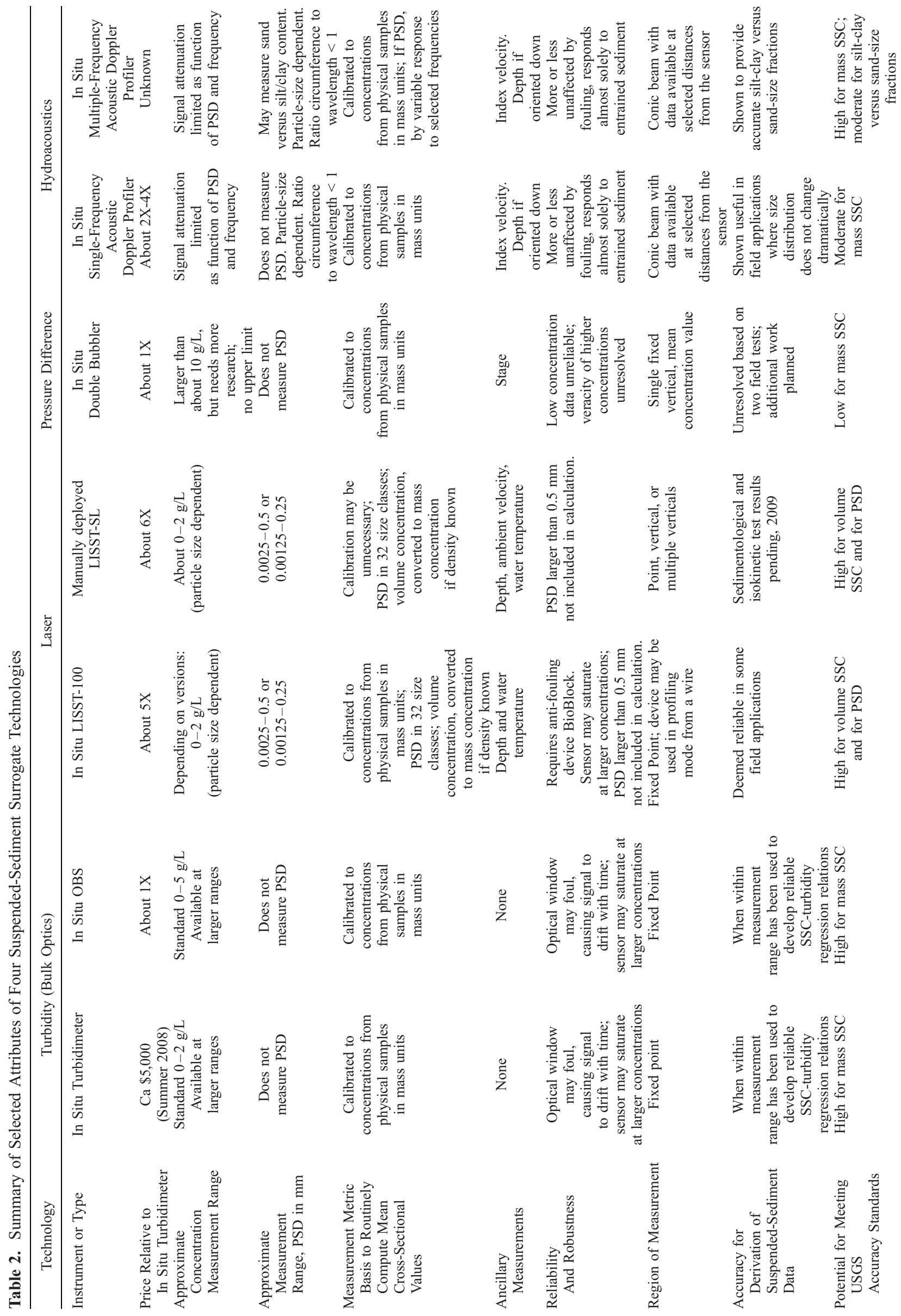


pended sediment discharge is determined from water discharge and computed, cross-sectional average SSC values.

[104] Advantages of the acoustic-backscatter technology are summarized as follows:

[105] 1. Unlike point measurements, acoustic backscatter measurements can cover a substantial part of the water depth or river cross section; they integrate orders of magnitude more flow than other methods that rely on at-a-point or single vertical measurements.

[106] 2. Sediment fluxes in the beam can be computed and empirically indexed to the mean cross-sectional SSC value. These data in turn can be used with continuous water discharge data to compute unit and daily value sediment fluxes at the monitoring site.

[107] 3. Unlike optic-based surrogate instruments, biological fouling is not a problem.

[108] 4. The approach is applicable for monitoring SSCs over the ranges of $0.01-20 \mathrm{~g} / \mathrm{L}$ for silt and clay and $0.01-$ $3 \mathrm{~g} / \mathrm{L}$ for sand.

[109] 5. Concentrations have been measured up to $2 \mathrm{~g} / \mathrm{L}$ by this technique.

[110] The limitations of the technology are summarized below:

[111] 1. Similar to optical surrogate techniques, a singlefrequency source cannot differentiate between changes in PSDs and changes in SSCs without calibration.

[112] 2. There is an optimal frequency for a given particle size and a somewhat narrow frequency range for which the method is appropriate for a given PSD.

[113] 3. Complex software is required for the reduction and analysis of the acoustic signals.

[114] 4. The purchase price of an in situ horizontally looking instrument is about double to triple that for a fully equipped in situ turbidimeter and about fourfold the price of a turbidimeter for an upward looking instrument.

[115] 5. Until standard operating procedures are developed and adopted for this technique, time requirements for the hydrographer to resolve the continuous SSC trace will not be trivial.

\section{Summary and Conclusions}

[116] Four advanced in situ technologies for monitoring fluvial suspended sediment transport are among instruments and techniques being tested by the USGS: turbidity (bulk optics), laser optics, pressure difference, and acoustic backscatter. Although none is a panacea for sediment monitoring needs in all rivers, the capability for consistent, large-scale monitoring of suspended sediment transport in many of the world's rivers may be possible.

[117] Table 2 summarizes selected attributes of the four technologies that are germane to their potential use as a sediment surrogate technology. Each technology, with the possible exceptions of manually deployed laser optic instruments, requires periodic calibration with data produced from traditionally collected water samples to calculate the mean value in the cross section. When properly configured and deployed, each is capable of providing a dense and continuous time series of SSC for use in computation of continuous suspended sediment transport. Laser optics and possibly multifrequency acoustic backscatter may provide the added capability of sediment discharge computations by particle size class. The ability to determine 
continuous, high-frequency, time series of SSC is a major advantage over traditional data collection techniques, obviating the need for routine, potentially subjective interpolations between sample values, and providing the capability to determine high-frequency SSC and PSD fluctuations not revealed by traditional measurements. Calibrations with somewhat larger uncertainty bounds might be considered more acceptable in that the vastly increased derived data density preclude the routine need for sediment trace interpolations.

[118] The applicability of each technology is dictated in part based on the physical and hydrological characteristics of the monitoring site; monitoring objectives; and the instrument's advantages and limitations. Each deployed surrogate instrument provides time series data representative of the sedimentological characteristics in but a fraction of the cross section. Both optical technologies provide at-apoint SSC data during periods that in-stream SSC values remain below the instrument's saturation limit. The SSC data provided by laser optics are computed from PSDs associated with each measurement.

[119] An instrument's measurement realm is an important factor in correlating the measurements to mean crosssectional SSC values. Assuming production of reliable data collected from the instrument realm, SSCs computed utilizing acoustic backscatter technology (employing a profile of vertical or horizontal measurements) may correlate better with the mean SSC value for the river cross section than those computed with the pressure difference method, which in turn may be better than those computed from at-a-point turbidity or laser optic measurements.

[120] Nevertheless, the most ubiquitous in situ surrogate technology utilizes turbidimeters, which have been shown to provide useful data for computing SSCs in a number of field settings. However, issues associated with instrument sensor saturation can result in failure to record reliable data at the higher values of SSCs that tend to be the most influential in sediment transport. SSCs computed from ata-point turbidity data may not be representative of the mean cross-sectional SSC, particularly when sand-size material composes an appreciable fraction of total suspended sediment transport. Biological fouling can reduce signal integrity in the absence of a mechanical wiper or manual cleaning to keep the optical window clean. Turbidimeter costs are a small fraction of the annual cost of monitoring suspended sediment transport using traditional techniques, but the potential for increased site visits for maintenance may result in increased operating costs.

[121] In situ laser optic instruments also suffer from the drawbacks associated with sensor saturation, biological fouling, and at-a-point measurement limitation characteristics of in situ turbidimeters. Additionally, laser data are in the form of volume SSC; mass SSC may be calculated only if particle density is known or can be reliably inferred. The purchase price of an in situ laser optical instrument (LISST100 ) is about 5 times the cost of a fully equipped in situ turbidimeter. However, these instruments have the major advantage in providing continuous PSDs from which the volumetric SSCs are inferred.

[122] The pressure difference technology is designed for monitoring SSCs exceeding about $10 \mathrm{~g} / \mathrm{L}$ in a single vertical, which is near or above the maximum range of the other technologies examined herein. The purchase price of this relatively uncomplicated technology is similar to that for a turbidimeter. It is relatively robust in that it integrates the density of a water column as opposed to a single vertical, and it is not subject to biological fouling. The theoretical underpinnings of this technology are straightforward. However, performance of the pressure difference technology has been marginal at best in field tests in Puerto Rico (maximum concentrations of about $18 \mathrm{~g} / \mathrm{L}$ ) and Arizona (maximum concentrations of about $380 \mathrm{~g} / \mathrm{L}$ ). Because this technology addresses a unique monitoring niche for measurements in highly concentrated or hyperconcentrated flows, and because of large benefits associated with the production of a dense time series of surrogate measurements, it is remains under consideration for future testing and use.

[123] Acoustic backscatter technology shows the most promise for meeting the needs of large-scale fluvial sediment monitoring programs. The technology integrates several orders of magnitude more flow than those technologies associated with point measurements. SSC data computed from backscatter data obtained using a three-frequency instrument array and appropriate postprocessing techniques ranged from 0.01 to $20 \mathrm{~g} / \mathrm{L}$ (silt- and clay-size material) and $0.01-3 \mathrm{~g} / \mathrm{L}$ (sand-size material). These data were deemed by the principal investigators to be at least as accurate, within $5 \%$, as measurements by traditional techniques. At present, the cost of using a three-frequency Doppler array (three separate instruments) is about sixfold that of a fully equipped in situ turbidimeter. Although at least one multifrequency ABS is commercially available, it lacks Doppler velocity capability. Until a multifrequency Doppler velocity profiler becomes commercially available, the cost of such an array will probably remain comparatively high. Fortunately, there are indications that development of such selfcontained, multifrequency Doppler velocity units are planned, making more economic monitoring of sediment transport possible in the future, at least under some hydrological and sedimentological conditions.

[124] Most suspended sediment data obtained by federal agencies today have their underpinnings in instruments and techniques conceived before the mid-1940s. Hence, the prospect of broad application of one or more suspendedsediment surrogate technologies presented herein, and perhaps others in development, is a revolutionary concept in fluvial sedimentology. The benefits of such applied capability could be enormous, providing for safer, more frequent and consistent, arguably more accurate, and ultimately less expensive fluvial data collection for use in managing the world's sedimentary resources.

\section{References}

Agrawal, Y. C., and H. C. Pottsmith (1994), Laser diffraction particle sizing in STRESS, Cont. Shelf Res., 14, 1101-1121, doi:10.1016/02784343(94)90030-2.

Agrawal, Y. C., and H. C. Pottsmith (2000), Instruments for particle size and settling velocity observations in sediment transport, Mar. Geol., 168(1-4), 89-114, doi:10.1016/S0025-3227(00)00044-X.

Agrawal, Y. C., and H. C. Pottsmith (2006), The isokinetic streamlined suspended-sediment profiling LISST-SL: Status and field results, paper presented at 8th Federal Interagency Sedimentation Conference, Advisory Comm. on Water Inf., Reno, Nevada. (Available at http://pubs.usgs.gov/ misc_reports/FISC_1947-2006/pdf/1st-7thFISCs-CD/8thFISC/Session\%202C1_Agrawal.pdf) 
Agrawal, Y. C., A. Whitmire, O. A. Mikkelsen, and H. C. Pottsmith (2008), Light scattering by random shaped particles and consequences on measuring suspended sediments by laser diffraction, J. Geophys. Res., 113, C04023, doi:10.1029/2007JC004403.

Anderson, C. A. (2005), Turbidity, in National Field Manual for the Collection of Water-Quality Data, U.S. Geol. Surv. Tech. of Water Resour. Invest., Book 9, U. S. Geol. Surv., Reston, Va. (Available at http://water. usgs.gov/owq/FieldManual/Chapter6/6.7 contents.html)

Bent, G. C., J. R. Gray, K. P. Smith, and G. D. Glysson (2003), A synopsis of technical issues for monitoring sediments in highway and urban runoff, in The National Highway Runoff Data and Methodology Synthesis, Publ. FHWA-EP-03-054, edited by G. E. Granato et al., pp. 113-163, U. S. Dept. of Transportation, Washington, D. C. (Available at http:// ma.water.usgs.gov/fhwa/products/ofr00497.pdf)

Beverage, J. P., and J. K. Culbertson (1964), Hyperconcentrations of suspended sediment, Proc. Am. Soc. Civ. Eng., 90, 117-128.

Bogen, J., T. Fergus, and D. E. Walling (2003), Erosion and sediment transport in rivers, technological and methodological advances, Int. Assoc. Hydrol. Sci. Publ. 283, 238 pp.

Buchanan, P. A., and C. A. Ruhl (2000), Summary of suspended-solids concentration data, San Francisco Bay, California, Water Year 1998, U.S. Geol. Surv. Open File Rep., 00-88, 41 pp.

Christensen, V. G., J. Xiaodong, and A. C. Ziegler (2000), Regression analysis and real-time water-quality monitoring to estimate constituent concentrations, loads, and yields in the Little Arkansas River, south-central Kansas, 1995-99, U.S. Geol. Surv. Water Resour. Invest. Rep., 00-4126, 36 pp. (Available at http://ks.water.usgs.gov/Kansas/pubs/reports/wrir.004126.html)

Conner, C. S., and A. M. De Visser (1992), A laboratory investigation of particle size effects on optical backscatterance sensor, Mar. Geol., 108, 151-159, doi:10.1016/0025-3227(92)90169-I.

D\&A Instrument Company (1991), OBS-1 \& 3 Instruction Manual, 41 pp., Port Townsend, Wash.

Davis, B. E. (2005), A guide to the proper selection and use of Federally approved sediment and water-quality samplers, U. S. Geol. Surv. Open File Rep., 2005-1087, 20 pp. (Available at http://pubs.usgs.gov/of/2005/ $1087 /)$

Deines, K. L. (1999), Backscatter estimation using broadband acoustic Doppler current profilers, paper presented at Sixth Working Conference on Current Measurement, IEEE, San Diego, Calif.

Downing, A., P. D. Thorne, and C. E. Vincent (1995), Backscattering from a suspension in the near field of a piston transducer, J. Acoust. Soc. Am., 97(3), 1614-1620, doi:10.1121/1.412100.

Downing, J. P. (1983), An optical instrument for monitoring suspended particles in ocean and laboratory, paper presented at OCEANS 1983, Inst. of Electr. and Electron. Eng., San Francisco, Calif.

Downing, J. P. (1996), Suspended sediment and turbidity measurements in streams: What they do and do not mean, paper presented at Automatic Water Quality Monitoring Workshop, B. C. Water Quality Monitor. Agree. Coord. Comm., Richmond, British Columbia, Canada.

Downing, J. P., R. W. Sternberg, and C. R. B. Lister (1981), New instrumentation for the investigation of sediment suspension processes in the shallow marine environment, Mar. Geol., 42, 19-34, doi:10.1016/00253227(81)90156-0.

Edwards, T. E., and G. D. Glysson (1999), Field methods for collection of fluvial sediment, in Techniques of Water-Resources Investigations, Book 3, 89 pp., U.S. Geol. Surv., Reston, Va. (Available at http://water.usgs. gov/osw/techniques/Edwards-TWRI.pdf)

Federal Interagency Sedimentation Project (1940), Field practice and equipment used in sampling suspended sediment, Interagency Rep. 1, 175 pp., Hydraul. Lab., Univ. of Iowa, Iowa City. (Available at http://fisp.wes. army.mil/Report\%20)

Federal Interagency Sedimentation Project (1941), Laboratory investigation of suspended-sediment samplers, Interagency Rep. 5, 99 pp., Hydraul. Lab., Univ. of Iowa, Iowa City. (Available at http://fisp.wes.army.mil/ Report\%205.pdf.

Flagg, C. N., and S. L. Smith (1989), On the use of the acoustic Doppler current profiler to measure zooplankton abundance, Deep Sea Res., 36(3), 455-474, doi:10.1016/0198-0149(89)90047-2.

Flammer, G. H. (1962), Ultrasonic measurement of suspended sediment, U.S. Geol. Surv. Bull. 1141-A, 48 pp., Govt. Printing Off., Washington, D.C.

Gartner, J. W. (2004), Estimating suspended solids concentrations from backscatter intensity measured by acoustic Doppler current profiler in San Francisco Bay, California, Mar. Geol., 211, 169-187, doi:10.1016/ j.margeo.2004.07.001.
Gartner, J. W., R. T. Cheng, P. F. Wang, and K. Richter (2001), Laboratory and field evaluations of LISST-100 instrument for suspended particle size determinations, Mar. Geol., 175(1-4), 199-219, doi:10.1016/S00253227(01)00137-2.

Gartner, J. W., D. S. Mueller, G. R. Wall, and J. R. Gray (2003), Breakout session 4: Other fluvial-sediment surrogates, paper presented at Federal Interagency Workshop on Turbidity and Other Sediment Surrogates, Fed. Interagency Subcomm. on Sediment., Reno, Nevada. (Available at http:// pubs.usgs.gov/circ/2003/circ1250/)

Glysson, G. D. (1987), Sediment-transport curves, U.S. Geol. Surv. Open File Rep., 87-218, 47 pp. (Available at http://pubs.er.usgs.gov/usgspubs/ ofr/ofr87218)

Glysson, G. D. (1989), 100 years of sedimentation study by the USGS, in Proceedings of the International Symposium, Sediment Transport Modeling, edited by S. S. Y. Wang, pp. 260-265, Am. Soc. of Civ. Eng., New Orleans, La.

Glysson, G. D., and J. R. Gray (1997), Coordination and standardization of Federal sedimentation activities, in Expanding Sediment Research Capabilities in Today's U.S. Geological Survey, edited by J. R. Gray, 3 pp., U. S. Geol. Surv., St. Petersburg, Fla. (Available at http://water.usgs.gov/ osw/techniques/sedtech21/gray.html)

Graf, J. B., L. Wirt, E. K. Swanson, G. G. Fisk, and J. R. Gray (1995), Streamflow transport of radionuclides in the Puerco and Little Colorado River basins, Arizona and New Mexico, U. S. Geol. Surv. Water Supply Pap., 2459, 89 pp. (Available at http://pubs.er.usgs.gov/usgspubs/wsp/ wsp2459)

Gray, J. R. (2003a), The need for sediment surrogate technologies to monitor fluvial-sediment transport, in Proceedings of the Federal Interagency Sedimentation Workshop on Turbidity and Other Sediment Surrogates, edited by J. R. Gray and G. D. Glysson, U. S. Geol. Surv. Circ., vol. 1250, 4 pp. (Available at http://water.usgs.gov/osw/techniques/ TSS/gray.pdf)

Gray, J. R. (2003b), U.S. Geological Survey suspended-sediment surrogate research, Part I: Call for a sediment monitoring instrument and analysis research program, paper presented at Virginia Water Research Symposium 2003, Water Resource Management for the Commonwealth, Va. Polytech. Inst. and State Univ., Blacksburg.

Gray, J. R. (Ed.) (2005), Proceedings of the Federal Interagency Sediment Monitoring Instrument and Analysis Research Workshop, Flagstaff, Arizona, 9-11 September, U.S. Geol. Surv. Circ., 1276, 46 pp. (Available at http://pubs.usgs.gov/circ/2005/1276/)

Gray, J. R., and J. W. Gartner (2004), Surrogate technologies for continuous suspended-sediment monitoring in the United States, paper presented at 9th International Symposium on River Sedimentation, Tsinghua Univ., Yichang, China.

Gray, J. R., and G. D. Glysson (2005), Attributes of a sediment monitoring instrument and analysis research program, paper presented at Federal Interagency Sediment Monitoring Instrument and Analysis Research Workshop, U. S. Geol. Surv., Flagstaff, Ariz. (Available at http://water. usgs.gov/osw/techniques/sediment/sedsurrogate2003workshop/gray_ glysson.pdf)

Gray, J. R., and F. J. M. Simões (2008), Estimating sediment discharge, in Sedimentation Engineering-Processes, Measurements, Modeling, and Practice, Manual 110, edited by M. Garcia, pp. 1067-1088, Am. Soc. of Civ. Eng., Reston, Va.

Gray, J. R., G. D. Glysson, and D. S. Mueller (2002), Comparability and accuracy of fluvial-sediment data-a view from the U.S. Geological Survey, in paper presented at Specialty Conference, Hydraulic Measurements and Experimental Methods, Am. Soc. of Civ. Eng., Estes Park, Colo. (Available at http://water.usgs.gov/osw/techniques/asce.pdf)

Gray, J. R., T. S. Melis, E. Patiño, M. C. Larsen, D. J. Topping, P. P. Rasmussen, and C. Figueroa-Alama (2003a), U.S. Geological Survey research on surrogate measurements for suspended sediment, in Proceedings of the 1st Interagency Conference on Research in Watersheds, edited by K. Renard et al., pp. 95-100, U. S. Dept. of Agric., Benson, Ariz.

Gray, J. R., D. J. Gooding, T. S. Melis, D. J. Topping, and P. P. Rasmussen (2003b), U.S. Geological Survey suspended-sediment surrogate research, Part II: Optic technologies, paper presented at Virginia Water Research Symposium 2003, Water Resource Management for the Commonwealth, Va. Polytech. Inst. and State Univ., Blacksburg.

Gray, J. R., E. Patiño, and M. C. Larsen (2003c), U.S. Geological Survey suspended-sediment surrogate research, Part III: Acoustic and pressuredifferential technologies, paper presented at Virginia Water Research Symposium 2003, Water Resource Management for the Commonwealth, Va. Polytech. Inst. and State Univ., Blacksburg. 
Gray, J. R., Y. C. Agrawal, and H. C. Pottsmith (2004), The LISST-SL streamlined isokinetic suspended-sediment profiler, paper presented at 9th International Symposium on River Sedimentation, Tsinghua Univ., Yichang, China. (Available at http://water.usgs.gov/osw/techniques/ Lisst_Gray_Agrawal_Pottsmith.pdf)

Gray, J. R., G. D. Glysson, and T. K. Edwards (2008), Suspended-sediment samplers and sampling methods, in Sedimentation Engineering, Manual 110, chap. 5.3, pp. 318-337, Am. Soc. of Civ. Eng., Reston, Va.

Hamilton, L. J., Z. Shi, and S. Y. Zhang (1998), Acoustic backscatter measurements of estuarine suspended cohesive sediment concentration profiles, J. Coastal Res., 14(4), 1213-1224.

Hay, A. E. (1991), Sound scattering from a particle-laden, turbulent jet, J. Acoust. Soc. Am., 90(4), 2055-2074.

Hay, A. E., and J. Sheng (1992), Vertical profiles of suspended sand concentration and size from multi-frequency acoustic backscatter, J. Geophys. Res., 97(C10), 15,661-15,677, doi:10.1029/92JC01240.

Heywood, K. J., S. Scrope-Howe, and E. D. Barton (1991), Estimation of zooplankton abundance from shipborne ADCP backscatter, Deep Sea Res., 38(6), 677-691, doi:10.1016/0198-0149(91)90006-2.

Holdaway, G. P., P. D. Thorne, D. Flatt, S. E. Jones, and D. Prandle (1999), Comparison between ADCP and transmissometer measurements of suspended sediment concentration, Cont. Shelf Res., 19, 421-441, doi:10.1016/S0278-4343(98)00097-1.

Jay, D. A., P. Orton, D. J. Kay, A. Fain, and A. M. Baptisa (1999), Acoustic determination of sediment concentrations, settling velocities, horizontal transports and vertical fluxes in estuaries, paper presented at 6th Working Conference on Current Measurement, IEEE, San Diego, Calif.

Kineke, G. C., and R. W. Sternberg (1992), Measurements of high concentration suspended sediments using the optical backscatterance sensor, Mar. Geol., 108, 253-258, doi:10.1016/0025-3227(92)90199-R.

Koltun, G. F., M. Eberle, J. R. Gray, and G. D. Glysson (2006), User's manual for the Graphical Constituent Loading Analysis System (GCLAS), in Techniques and Methods, Book 4, chap. C1, 50 pp., U.S. Geol. Surv., Reston, Va. (Available at http://pubs.er.usgs.gov/usgspubs/ $\mathrm{tm} / \mathrm{tm} 4 \mathrm{C} 1)$

Konrad, C., H. C. Pottsmith, T. S. Melis, and D. M. Rubin (2006), Realtime analysis of concentrated fluvial suspended sediments, paper presented at 8th Federal Interagency Sedimentation Conference, U. S. Geol. Surv., Reno, Nev. (Available at http://pubs.usgs.gov/misc_reports/ FISC_1947-2006/pdf/1st-7thFISCs-CD/8thFISC/Session\%208C-2_Konrad. pdf)

Land, J. M., and P. D. Jones (2001), Acoustic measurement of sediment flux in rivers and near-shore waters, paper presented at 7 th Federal Interagency Sedimentation Conference, U. S. Geol. Surv., Reno, Nev. (Available at http://pubs.usgs.gov/misc_reports/FISC_1947-2006/pdf/ 1st-7thFISCs-CD/7thFISC/7Fisc-V1/7FISC1-3.pdf)

Landers, M. N. (2003), Summary of blind sediment reference sample measurement session, in Proceedings of the Federal Interagency Workshop on Turbidity and Other Sediment Surrogates, edited by J. R. Gray and G. D. Glysson, U.S. Geol. Surv. Circ., vol. 1250, pp. 29-30. (Available at http://water.usgs.gov/osw/techniques/turbidity.html)

Larsen, M. C., C. Figueroa-Alamo, J. R. Gray, and W. Fletcher (2001), Continuous automated sensing of streamflow density as a surrogate for suspended-sediment concentration sampling, paper presented at 7th Federal Interagency Sedimentation Conference, U. S. Geol. Surv., Reno, Nev. (Available at http://pubs.usgs.gov/misc_reports/FISC_1947-2006/ pdf/1st-7thFISCs-CD/7thFISC/7Fisc-V1/7FISC $1-3 . p d f)$

Lewis, J. (2002), Estimation of suspended sediment flux in streams using continuous turbidity and flow data coupled with laboratory concentrations, in Proceedings of the Federal Interagency Workshop on Turbidity and Other Sediment Surrogates, edited by J. R. Gray and G. D. Glysson, U.S. Geol. Surv. Circ., 1250, 3 pp. (Available at http://water.usgs.gov/ osw/techniques/TSS/LewisTSS.pdf)

Lewis, A. J., and T. C. Rasmussen (1999), Determination of suspended sediment concentrations and particle size distributions using pressure measurements, J. Environ. Qual., 28, 1490-1496.

Libicki, C., K. W. Bedford, and J. F. Lynch (1989), The interpretation and evaluation of a 3-MHz acoustic backscatter device for measuring benthic boundary layer sediment dynamics, J. Acoust. Soc. Am., 85(4), $1501-$ 1511, doi:10.1121/1.397351.

Lohrman, A., and C. Huhta (1994), Plume measurement system (Plumes) calibration experiment, dredging research program, Tech. Rep. DRP-943, 152 pp., U. S. Army Corps of Eng., Washington, D.C.

Lorke, A., D. F. McGinnis, P. Spaak, and A. Wuest (2004), Acoustic observations of zooplankton in lakes using Doppler current profiler, Freshwater Biol., 49, 1280-1292, doi:10.1111/j.1365-2427.2004.01267.x.
Ludwig, K. A., and D. M. Hanes (1990), A laboratory evaluation of optical backscatterance suspended solids sensors exposed to sand-mud mixtures, Mar. Geol., 94, 173-179, doi:10.1016/0025-3227(90)90111-V.

Meade, R. H., and R. S. Parker (1985), Sediment in rivers of the United States, U.S. Geol. Surv. Water Supply Pap., 2275, 49-60.

Melis, T. S., D. J. Topping, and D. M. Rubin (2003), Testing laser-based sensors for continuous in situ monitoring of suspended sediment in the Colorado River, Arizona, in Erosion and Sediment Transport Measurement in Rivers, Technological and Methodological Advances, Publ., vol. 203, edited by J. Bogen et al., pp. 21-27, Int. Assoc. of Hydrol. Sci., Geneva.

Mol, J.-W. (2003), Sedimentation estimation from ADCP measurements, Hydro Int., 7(6). (Available at http://www.hydro-international. com/issues/articles/id17-Sedimentation_Estimation_from_ADCP_ Measurements.html)

Nelson, M. E., and P. C. Benedict (1950), Measurement and analysis of suspended sediment loads in streams, Am. Soc. Civ. Eng. Trans., 2450, $891-918$

Nolan, K. M., J. R. Gray, and G. D. Glysson (2005), Introduction to suspended-sediment sampling [CD-ROM], U.S. Geol. Surv. Sci. Invest. Rep., 2005-5077. (Available at http://pubs.er.usgs.gov/pubs/sir/ sir20055077)

Osterkamp, W. R., P. Heilman, and L. J. Lane (1998), Economic considerations of a continental sediment-monitoring program, Int. J. Sediment. Res., 13(4), 12-24.

Osterkamp, W. R., et al. (2004), An invitation to participate in a North American sediment-monitoring network, Eos Trans. AGU, 84(40), 386.

Pimentel, D., et al. (1995), Environmental and economic costs of soil erosion and conservation benefits, Science, 267, 1117-1123, doi:10.1126/ science.267.5201.1117.

Porterfield, G. (1972), Computation of fluvial-sediment discharge, in Techniques of Water-Resource Investigations, Book 3, chap. C3, 66 pp., U. S. Geol. Surv., Reston, Va. (Available at http://water.usgs.gov/pubs/twri/ twri3-c3/)

Pratt, T., and T. Parchure (2003), OBS calibration and field measurements, in Proceedings of the Federal Interagency Workshop on Turbidity and Other Sediment Surrogates, edited by J. R. Gray and G. D. Glysson, U.S. Geol. Surv. Circ., 1250, 31-46. (Available at http://pubs.usgs.gov/circ/ 2003/circ 1250/)

Pruitt, B. A. (2003), Uses of turbidity by States and Tribes, in Proceedings of the Federal Interagency Workshop on Turbidity and Other Sediment Surrogates, edited by J. R. Gray and G. D. Glysson, U.S. Geol. Surv. Circ., 1250, 31-46. (Available at http://pubs.usgs.gov/circ/2003/ circ1250/)

Rainwater, F. H. (1962), Stream composition of the conterminous United States, Hydrol. Invest. Atlas HA-61, U.S. Geol. Surv., Reston, Va.

Rasmussen, T. J., A. C. Ziegler, and P. P. Rasmussen (2005), Estimation of constituent concentrations, densities, loads, and yields on Lower Kansas River, Northeast Kansas, using regression models and continuous waterquality modeling, January 2000 through December 2003, U.S. Geol. Surv. Sci. Invest. Rep., 2005-5165, 117 pp. (Available at http://pubs. usgs.gov/sir/2005/5165/)

Reichel, G., and H. P. Nachtnebel (1994), Suspended sediment monitoring in a fluvial environment: Advantages and limitations applying an acoustic Doppler current profiler, Water Res., 28(4), 751-761, doi:10.1016/ 0043-1354(94)90083-3.

Schoellhamer, D. H., and S. A. Wright (2003), Continuous measurement of suspended-sediment discharge in rivers by use of optical backscatterance sensors, in Erosion and Sediment Transport Measurement in Rivers, Technological and Methodological Advances, Publ. 283, edited by J. Bogen et al., pp. 28-36, Int. Assoc. of Hydrol. Sci., Geneva.

Schoellhamer, D. H., P. A. Buchanan, and N. K. Ganju (2002), Ten years of continuous suspended sediment concentration monitoring in San Francisco Bay and Delta, paper presented at Turbidity and Other Sediment Surrogates Workshop, U. S. Geol. Surv., Reno, Nev. (Available at http:// water.usgs.gov/osw/techniques/TSS/schoelhamer.pdf)

Schott, F., and W. Johns (1987), Half-year-long measurements with a buoymounted acoustic Doppler current profiler in the Somali Current, J. Geophys. Res., 92(C5), 5169-5176, doi:10.1029/JC092iC05p05169.

Sheng, J., and A. E. Hay (1988), An examination of the spherical scatter approximation in aqueous suspensions of sand, J. Acoust. Soc. Am., 83(2), 598-610, doi:10.1121/1.396153.

Skinner, J. V. (1989), History of the Federal Interagency Sedimentation Project, in Proceedings of the International Symposium, Sediment Transport Modeling, edited by S. S. Y. Wang, pp. 266-271, Am. Soc. of Civ. Eng., New Orleans, La. 
Smith, R. A., R. B. Alexander, and M. G. Wolman (1987), Water-quality trends in the nation's rivers, Science, 235, 1607-1615, doi:10.1126/ science.235.4796.1607.

Sutherland, T. F., P. M. Lane, C. L. Amos, and J. Downing (2000), The calibration of optical backscatter sensors for suspended sediment of varying darkness levels, Mar. Geol., 162, 587-597, doi:10.1016/S00253227(99)00080-8.

Thevenot, M. M., and N. C. Kraus (1993), Comparison of acoustical and optical measurements of suspended material in the Chesapeake Estuary, J. Mar. Environ. Eng., 1, 65-79.

Thevenot, M. M., T. L. Prickett, and N. C. Kraus (1992), Tylers Beach, Virginia, dredged material plume monitoring project 27 September to 4 October 1991, Tech. Rep. DRP-92-7, 204 pp., U. S. Army Corps of Eng., Washington, D.C.

Thorne, P. D., C. E. Vincent, P. J. Harcastle, S. Rehman, and N. Pearson (1991), Measuring suspended sediment concentrations using acoustic backscatter devices, Mar. Geol., 98, 7-16, doi:10.1016/0025-3227(91) 90031-X.

Topping, D. J., T. S. Melis, D. M. Rubin, and S. A. Wright (2004), Highresolution monitoring of suspended-sediment concentration and grain size in the Colorado River in Grand Canyon using a laser acoustic system, paper presented at 9th International Symposium on River Sedimentation, Tsinghua Univ., Yichang, China.

Topping, D. J., S. A. Wright, T. S. Melis, and D. M. Rubin (2007), Highresolution measurement of suspended-sediment concentrations and grain size in the Colorado River in Grand Canyon using a multi-frequency acoustic system, paper presented at 10th International Symposium on River Sedimentation, World Assoc. for Sediment. and Erosion Res., Moscow, Russia.

Traykovski, P., R. J. Latter, and J. D. Irish (1999), A laboratory evaluation of the LISST instrument using natural sediments, Mar. Geol., 159, 355367, doi:10.1016/S0025-3227(98)00196-0.

Uhrich, M. A. (2002), Determination of total and clay suspended-sediment loads from instream turbidity data in the North Santiam River Basin,
Oregon, 1998-2002, in Proceedings of the Federal Interagency Workshop on Turbidity and Other Sediment Surrogates, edited by J. R. Gray and G. D. Glysson, U. S. Geol. Surv. Circ., 1250, 3 pp. (Available at http://water.usgs.gov/pubs/circ/2003/circ1250/)

Uhrich, M. A., and H. M. Bragg (2003), Monitoring instream turbidity to estimate continuous suspended-sediment loads and yields and clay-water volumes in the Upper North Santiam River Basin, Oregon, 1998-2000, U.S. Geol. Surv. Water Resour. Invest. Rep., 03-4098, 44 pp. (Available at http://pubs.usgs.gov/wri/WRI03-4098/)

Urick, R. J. (1975), Principles of Underwater Sound, 2nd ed., 384 pp., McGraw Hill, New York.

U. S. Department of Agriculture (1965), Proceedings of the Federal InterAgency Sedimentation Conference, Misc. Publ. 970, 933 pp., Washington, D. C.

U.S. Environmental Protection Agency (1999), Guidance manual for compliance with the Interim Enhanced Surface Water Treatment ruleTurbidity provisions, Rep. EPA 815-R-99-010, Washington, D.C.

Wall, G. R., E. A. Nystrom, and S. Litten (2006), Use of an ADCP to compute suspended-sediment discharge in the tidal Hudson River, New York, U.S. Geol. Surv. Sci. Invest. Rep., 2006-5055, 16 pp. (Available at http://pubs.usgs.gov/sir/2006/5055/)

Ziegler, A. C. (2003), Breakout session 1-Definition of optical methods for turbidity and data reporting, in Proceedings of the Federal Interagency Workshop on Turbidity and Other Sediment Surrogates, edited by J. R. Gray and G. D. Glysson, U.S. Geol. Surv. Circ., 1250, 9-13. (Available at http://water.usgs.gov/pubs/circ/2003/circ1250/)

J. W. Gartner, U.S. Geological Survey, 520 North Park Avenue, Tucson, AZ 85719, USA.

J. R. Gray, Office of Surface Water, U.S. Geological Survey, 12201 Sunrise Valley Drive, Reston, VA 20192, USA. (jrgray@usgs.gov) 